\title{
Dry season aerosol iron solubility in tropical northern Australia
}

\author{
V. Holly L. Winton ${ }^{1, a}$, Ross Edwards ${ }^{1}$, Andrew R. Bowie ${ }^{2,3}$, Melita Keywood ${ }^{4}$, Alistair G. Williams ${ }^{5}$, \\ Scott D. Chambers ${ }^{5}$, Paul W. Selleck ${ }^{4}$, Maximilien Desservettaz ${ }^{6}$, Marc D. Mallet ${ }^{7}$, and Clare Paton-Walsh ${ }^{6}$ \\ ${ }^{1}$ Physics and Astronomy, Curtin University, Perth, Western Australia, Australia \\ ${ }^{2}$ Antarctic Climate and Ecosystems CRC, University of Tasmania, Hobart, Tasmania, Australia \\ ${ }^{3}$ Institute for Marine and Antarctic Studies, University of Tasmania, Hobart, Tasmania, Australia \\ ${ }^{4}$ CSIRO, Ocean and Atmosphere, Aspendale, Victoria, Australia \\ ${ }^{5}$ Australian Nuclear Science and Technology Organisation, Sydney, New South Wales, Australia \\ ${ }^{6}$ Centre for Atmospheric Chemistry, University of Wollongong, Wollongong, New South Wales, Australia \\ ${ }^{7}$ Department of Chemistry, Physics and Mechanical Engineering, Queensland University of Technology, Brisbane, \\ Queensland, Australia \\ ${ }^{a}$ now at: British Antarctic Survey, Cambridge, UK
}

Correspondence to: V. Holly L. Winton (vicwin@bas.ac.uk)

Received: 18 May 2016 - Published in Atmos. Chem. Phys. Discuss.: 17 June 2016

Revised: 21 September 2016 - Accepted: 23 September 2016 - Published: 14 October 2016

\begin{abstract}
Marine nitrogen fixation is co-limited by the supply of iron (Fe) and phosphorus in large regions of the global ocean. The deposition of soluble aerosol Fe can initiate nitrogen fixation and trigger toxic algal blooms in nitrate-poor tropical waters. We present dry season soluble Fe data from the Savannah Fires in the Early Dry Season (SAFIRED) campaign in northern Australia that reflects coincident dust and biomass burning sources of soluble aerosol Fe. The mean soluble and total aerosol $\mathrm{Fe}$ concentrations were 40 and $500 \mathrm{ng} \mathrm{m}^{-3}$ respectively. Our results show that while biomass burning species may not be a direct source of soluble $\mathrm{Fe}$, biomass burning may substantially enhance the solubility of mineral dust. We observed fractional Fe solubility up to $12 \%$ in mixed aerosols. Thus, Fe in dust may be more soluble in the tropics compared to higher latitudes due to higher concentrations of biomass-burning-derived reactive organic species in the atmosphere. In addition, biomassburning-derived particles can act as a surface for aerosol Fe to bind during atmospheric transport and subsequently be released to the ocean upon deposition. As the aerosol loading is dominated by biomass burning emissions over the tropical waters in the dry season, additions of biomassburning-derived soluble Fe could have harmful consequences for initiating nitrogen-fixing toxic algal blooms. Future research is required to quantify biomass-burning-derived particle sources of soluble $\mathrm{Fe}$ over tropical waters.
\end{abstract}

\section{Introduction}

The deposition and dissolution of aerosols containing trace metals, such as iron (Fe), into the ocean may provide important micronutrients required for marine primary production in waters where they are depleted, such as the Southern Ocean (e.g. Boyd et al., 2000). Conversely, the deposition of soluble Fe can trigger toxic algal blooms in nutrient-poor tropical waters (LaRoche and Breitbarth, 2005). In these waters, $\mathrm{Fe}$ availability is a primary factor limiting nitrogen fixation (Rueter, 1988; Rueter et al., 1992; Falkowski, 1997; Knapp et al., 2016; Garcia et al., 2015). The addition of bioavailable $\mathrm{Fe}$ can influence inputs of newly fixed nitrogen into surface waters (Paerl et al., 1987; Rueter, 1988). A large fraction of nitrogen fixation is attributed to the filamentous, non-heterocystous cyanobacteria Trichodesmium (Paerl et al., 1994; Berman-Frank et al., 2001). Nitrogen fixation by Trichodesmium is Fe-limited in around $75 \%$ of the world oceans (Berman-Frank et al., 2001). Nitrogen fixation has a higher Fe requirement, reflected by higher $\mathrm{Fe}: \mathrm{C}$ quotas of Trichodesmium that range between 180 and $214 \mu \mathrm{mol} \mathrm{Fe} \mathrm{mol}^{-1} \mathrm{C}$ (Berman-Frank et al., 2001), compared with other marine phytoplankton, such as diatoms, which have $\mathrm{Fe}: \mathrm{C}$ quotas ranging between 1 and $7 \mu \mathrm{mol} \mathrm{mol}^{-1}$ (Kustka et al., 2003; Johnson et al., 1997; Rueter et al., 1992). Previous studies have investigated Fe availability as 
a limiting factor of marine primary production surrounding Australia. High Fe quotas and high nitrogen fixation rates of Trichodesmium were observed during bloom conditions from coastal waters north of Australia (Berman-Frank et al., 2001). In the oligotrophic waters of the northern Tasman Sea, southwestern Pacific, a 10-fold increase in nitrogen fixation was observed after a cyclone. This stimulated diazotrophy by enhanced phosphate availability in the absence of nitrate, and increased the dissolved Fe supply by wet deposition of Australian dust (Law et al., 2011). Dissolved Fe can also be supplied to the surface ocean by vertical mixing, hydrothermal inputs, and resuspension of marine sediments, in addition to wet and dry deposition of atmospheric sources (e.g. Tagliabue et al., 2010; Elrod et al., 2004; Mills et al., 2004).

Aerosols are an important source of new Fe to the global ocean (Boyd and Ellwood, 2010; Rubin et al., 2011). In tropical waters, several studies have shown that large toxic algal blooms, such as dinoflagellate Gymnodinium and cyanobacteria, have been stimulated by atmospheric deposition of nutrients. For example, the deposition of volcanic ash and Saharan dust may have alleviated the Fe limitation of toxic diazotrophic cyanophytes, thus fuelling nitrogen fixation of red tides in the eastern Gulf of Mexico (Lenes et al., 2008; Walsh and Steidinger, 2001). In addition to mineral dust, biomass burning could be a source of bioavailable Fe (Guieu et al., 2005; Ito, 2013, 2015) fuelling toxic algal blooms in tropical waters. The mortality of a coral reef in 1997 in western Sumatra, Indonesia, was linked to Fe fertilisation by Indonesian wildfires causing a giant red tide of Trichodesmium (Abram et al., 2003).

Australia is the primary source of atmospheric dust in the Southern Hemisphere, episodically supplying dust to the Tasman Sea and Southern Ocean (McTainsh et al., 2005). There are two general dust pathways from the Australian continent to the ocean (Bowler, 1976; Sprigg, 1982). First, the transport of dust southeast of Australia is associated with easterly moving frontal systems within the zonal westerly winds, and its deposition has been observed in marine sediment in the southwest Pacific Ocean and glaciers in New Zealand (Hesse and McTainsh, 2003; Johnston, 2001; Hesse, 1994; Marx et al., 2005). Second, the transport of dust northwest of Australia is associated with the easterly trade winds. In spite of the ubiquity of aeolian dust in Australia and the surrounding oceans, there are few studies investigating the composition of the dust on a continental scale. Some, but not all, Australian dust storms are thought to stimulate phytoplankton blooms (Shaw et al., 2008; Cropp et al., 2013; Gabric et al., 2010; Mackie et al., 2008). Soluble Fe deposition models indicate that dust and combustion aerosols from the Australian continent can be deposited in other coastal regions of Australia, such as the Indian Ocean and waters north of Australia (Ito, 2015; Mahowald et al., 2005). Studies from ice cores show that Australian dust and refractory black carbon (rBC), a proxy for biomass burning, can be transported over long range to Antarctica (Revel-Rolland et al., 2006; De Deckker et al., 2010; Bisiaux et al., 2012).

The fractional solubility of aerosol $\mathrm{Fe}$ is an important variable determining $\mathrm{Fe}$ availability for biological uptake. On a global scale, the large variability in the observed fractional Fe solubility results, in part, from a mixture of aerosol sources. Most studies assume that mineral dust aerosols represent the primary source of soluble Fe in the atmosphere (e.g. Baker and Croot, 2010). Mineral dust has a low fractional Fe solubility $(\sim 0.5-2 \%)$, whereas the presence of other soluble Fe sources, such as those originating from biomass burning and oil combustion have a higher fractional Fe solubility (Chuang et al., 2005; Guieu et al., 2005; Sedwick et al., 2007; Schroth et al., 2009; Ito, 2011). Although the total Fe content of fresh biomass burning aerosols is small, around 0.01$1.2 \%$ (Maenhaut et al., 2002; Yamasoe et al., 2000; Reid et al., 2005), estimates of fractional Fe solubility from fire combustion are large and variable (1-60\%). This large variability may be related to characteristics of the biomass and fire, as well as those of the underlying terrain (Ito, 2011; Paris et al., 2010). Ito (2015) shows that biomass-burning-derived soluble Fe contributes substantial inputs of soluble Fe to tropical and Southern Ocean waters downwind of Australia. Biomass burning could be an important source of soluble Fe to both tropical and Southern Ocean waters surrounding Australia.

Austral dry season rBC emissions in the Southern Hemisphere primarily occur in the Intertropical Convergence Zone (ITCZ) of Africa, Australia, and South America (Giglio et al., 2013). In Australia, biomass burning constitutes a large source of dry season aerosol emissions over northern and central Australia, and episodic austral summer wild fire in southern and eastern Australia (e.g. Meyer et al., 2008). In northern Australia, the dry season occurs from May-June (early dry season) to October-November (late dry season) (Andersen et al., 2005). To date, data for Australian soluble aerosol Fe sources are sparse (e.g. Mackie et al., 2005, 2008), and no soluble aerosol Fe data exist for Australia fire sources. The dry season tropical savannah burning region in northern Australia provides an ideal location to investigate biomassburning-derived fractional Fe solubility at the source. This study reports fractional Fe solubility estimates of mixed dust and fresh biomass-burning-derived (black-carbon-containing particles) Fe input to northern Australian waters. The study was conducted as part of the Savannah Fires in the Early Dry Season (SAFIRED) campaign from the Australian Tropical Atmospheric Research Station (ATARS), Gunn Point, Northern Territory, Australia.

\section{Methods}

\subsection{Study site}

The CSIRO Oceans and Atmosphere and the Australian Bureau of Meteorology has established a station at the ATARS, 

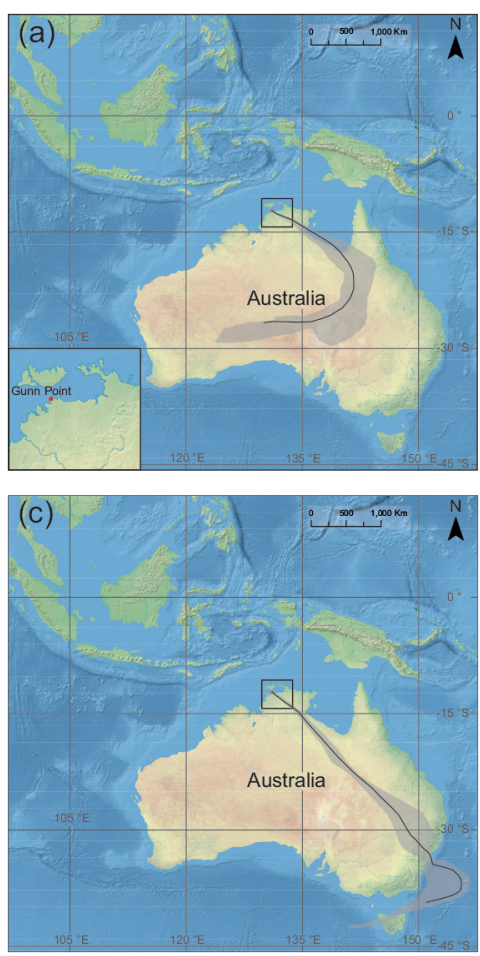
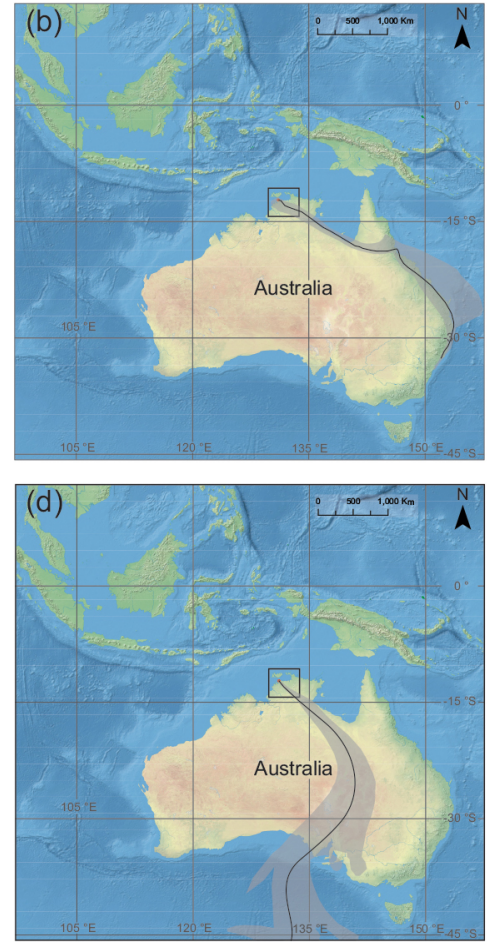

(e) Gunn Point, all wind 04/06/2014 1:05 to 27/06/2014 08:27 (1 min, N=32963)

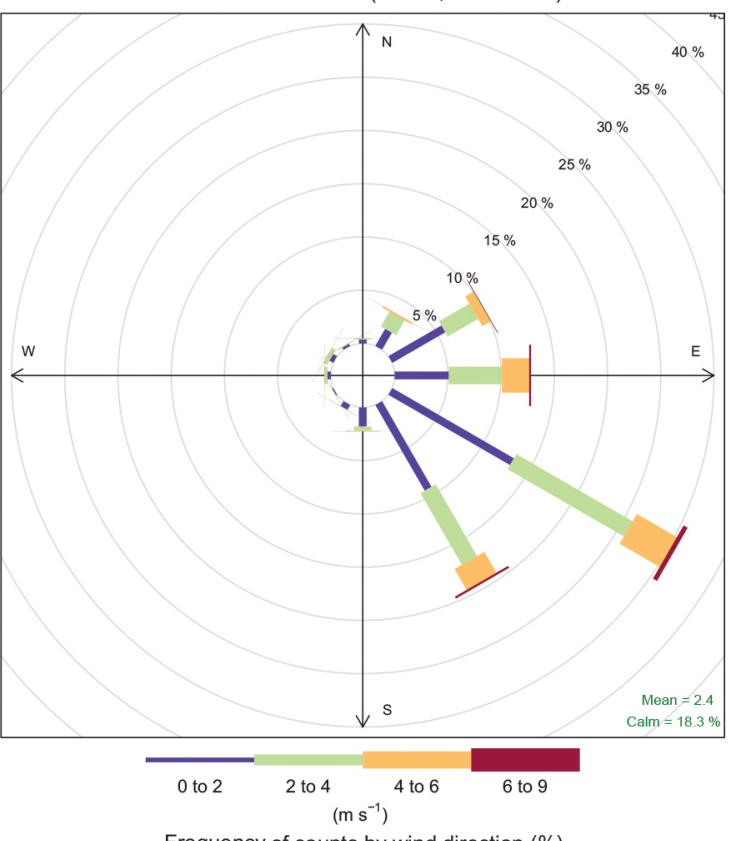

Frequency of counts by wind direction $(\%)$

Figure 1. Location of Gunn Point study site. Insert of the Northern Territory showing the Gunn Point site and the predominant air mass fetch regions for the June 2014 Gunn Point campaign. (a) Inland, low population density. (b) Coastal, moderate urban/industrial activity. (c) Inland, major urban/industrial activity. (d) Southerly. (e) Wind rose corresponding to the aerosol sampling duration. Wind rose created using the OpenAir package in R (Carslaw and Ropkins, 2012; Carslaw, 2014).

Gunn Point, Northern Territory, Australia $\left(12^{\circ} 14^{\prime} 56.6^{\prime \prime} \mathrm{S}\right.$, $131^{\circ} 02^{\prime} 40.8^{\prime \prime}$ E) (Fig. 1), monitoring meteorological parameters since 2010. The SAFIRED campaign occurred at the ATARS throughout June 2014 to investigate the chemical and physical properties of aerosols and gases in fresh and aged smoke plumes from biomass burning. A range of atmospheric species, including greenhouse gases, aerosols, and additional meteorological parameters, were monitored throughout the campaign. An overview of the campaign and description of the Gunn Point study site can be found in Mallet et al. (2016). The Northern Territory of Australia experiences hot, humid and wet conditions during the summer months of December through to March and dry conditions for the rest of the year. The savannah region gives rise to frequent fires between June and November. The large desert regions of central Australia lie to the south. During the sampling campaign, the strongest winds were predominantly from the southeast (Fig. 1).

\subsection{Sampling and blanks}

Daily aerosol filters were collected using two volumetric flow-controlled (VFC) high-volume aerosol samplers (Ecotech) equipped with a size-selective inlet (Ecotech) for particulate matter less than $10 \mu \mathrm{m}\left(\mathrm{PM}_{10}\right)$. The samplers were operated simultaneously. The first high-volume sam- pler was used to collect aerosols on acid-cleaned cellulose Whatman 41 filter sheets $(20 \times 25 \mathrm{~cm})$ to determine the soluble and total fraction of aerosol Fe and other trace elements. The second sampler was used to collect aerosol samples on quartz filters for elemental carbon and major cation and anion measurements. The high-volume aerosol samplers were located on the roof of a shipping container (at a height of $5 \mathrm{~m}$ above ground level - a.g.l.) at the ATARS. Loading and changing of aerosol collection substrates was carried out in a designated clean area at the ATARS. Aerosol laden filters were transferred into the individual zip-lock plastic bags immediately after collection and stored frozen until analysis at Curtin University and CSIRO Ocean and Atmosphere. A total of 23 trace metal aerosol filters were sampled daily between 4 and 27 June 2014 and are described in Table S1 in the Supplement.

For the trace element work, three types of filter blanks were carried out: (i) laboratory filter blanks $(n=6)$ (acidwashed Whatman 41 filter papers that underwent the laboratory procedures without going into the field), (ii) procedural filter blanks $(n=4)$ (filters that had been treated as for normal samples, i.e. acid-washed, but which were not otherwise used; once a week, during daily filter change-over, a procedural blank filter was mounted in the aerosol collector for 10 min without the collector pump in operation - this type 

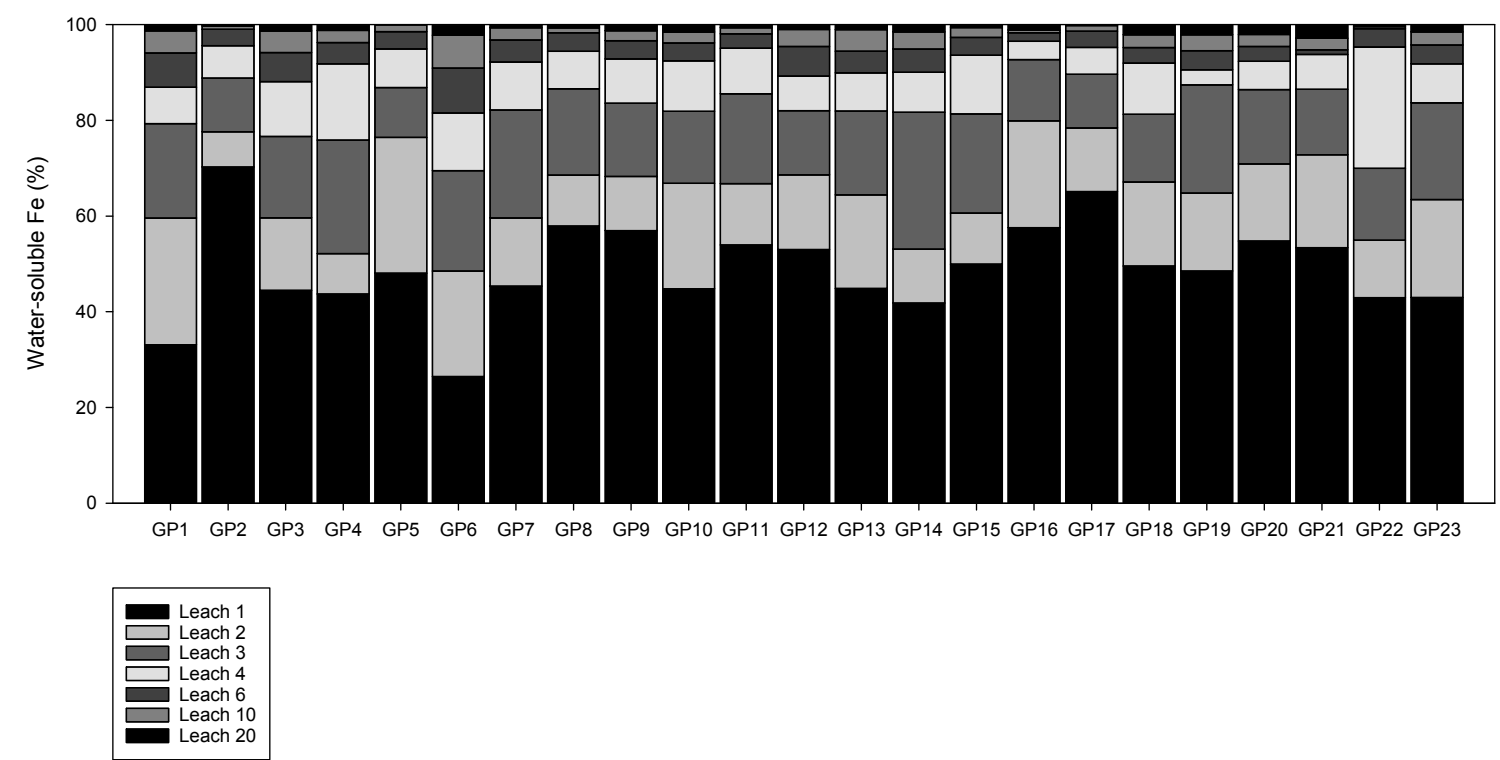

Figure 2. Fraction of water-soluble iron in sequential leaches of all $\mathrm{PM}_{10}$ samples from the SAFIRED campaign. Details of samples GP1 to GP23 can be found in Table S1 in the Supplement.

of filter provides an indication of the operational blank associated with the sampling procedure), and (iii) $24 \mathrm{~h}$ exposure filter blanks sampled at the beginning and end of the field campaign $(n=2)$ (filters treated like a procedural blank but left in the collector for $24 \mathrm{~h}$ without switching the collector on). Exposure blank filters for the elemental carbon and major ion measurements were run simultaneously with the trace element exposure blank filters.

\subsection{Trace element analysis}

All sample preparation and analysis for the trace element work was conducted in a trace metal clean laboratory (class 100 metal-free environment with high-efficiency particulate arrestance (HEPA) filtered air) at Curtin University following trace metal clean practices (e.g. Cutter et al., 2010). Details for ultra-pure reagents, ultra-pure water, acid washing of the apparatus, and Whatman 41 filters and filter subsampling are described in Winton et al. (2016a).

\subsubsection{Water solubility of aerosol iron}

There are a number of published methods for determining $\mathrm{Fe}$ solubility, and a number of operational definitions of $\mathrm{Fe}$ solubility. The discrepancy in soluble Fe methods, and the associated uncertainties, makes it difficult to compare results from different studies (Meskhidze et al., 2016). Although there are few estimates of soluble $\mathrm{Fe}$ in Australian dust and aerosols, for consistency we use the instantaneous water leaching scheme that was used in the Australian studies (Winton et al., 2015a, 2016a). It is widely reported in the literature that the soluble $\mathrm{Fe}$ concentration of aerosols de- creases exponentially with subsequent leaches (e.g. Wu et al., 2007; Fishwick et al., 2014; Aguilar-Islas et al., 2010). To determine how many leaches were required to extract the concentration of instantaneous soluble Fe from our samples, we carried out a sequential leach test on sample GP5 using 10 passes of $50 \mathrm{~mL}$ ultra-pure water. Leachates were collected in acid-washed polypropylene (PP) Corning ${ }^{\circledR}$ tubes and acidified with $1 \%$ ultra-pure $\mathrm{HCl}$. The experiment was repeated three times using three separate punches from the same filter sample. The exponential decrease in the soluble Fe concentration is illustrated in Fig. S1 in the Supplement and shows an exponential decrease in soluble Fe extraction with successive leaches. Even after 1 L of ultra-pure water was passed through the aerosol filter, soluble $\mathrm{Fe}$ was still being extracted. Therefore, soluble elements ( $\mathrm{Al}, \mathrm{Ti}, \mathrm{V}, \mathrm{Mn}, \mathrm{Fe}, \mathrm{Pb}$ ) were extracted from the Gunn Point filters using an instantaneous flow-through water leach consisting of 20 separate passes of $50 \mathrm{~mL}$ of ultra-pure water. A total volume of $1000 \mathrm{~mL}$ was filtered through each aerosol filter. We acknowledge that, beyond 20 leaches, soluble Fe could continue to leach out of the aerosols. Thus, the data reported here reflect "instantaneous" soluble Fe and may underestimate the total concentration of soluble Fe over greater leach volumes.

Soluble elements were extracted from aerosol filters (GP123), exposure blanks (EB1-2), and procedural blanks (PB14). Figure 2 highlights the percentage of soluble $\mathrm{Fe}$ in each leach. Similar to other studies of instantaneous soluble $\mathrm{Fe}$ (e.g. Boyd et al., 2010), around half of the soluble Fe is extracted in the first leach. Following the test on sample GP5, only leaches $1-4,6,10$, and 20 were collected and analysed. The concentration of the unanalysed leachates $5,7-$ 8 , and 11-19 was estimated by fitting a power law curve 
to the soluble Fe concentration in leachates $1-4,6,10$, and 20 for each sample. Total soluble Fe (and trace elements) was calculated by summing the soluble Fe concentration extracted from 20 leaches. The leachates from sample GP22 (as an example of a sample with a particularly high soluble Fe concentration) were re-filtered through $0.2 \mu \mathrm{m}$ acidcleaned polyvinylidene fluoride (PVDF) syringe filters to calculate the $<0.2 \mu \mathrm{m}$ soluble Fe fraction of the total soluble Fe. The concentration of soluble Fe in the $<0.2 \mu \mathrm{m}$ fraction of the leachate contained $70 \%$ of the total soluble $\mathrm{Fe}$ in GP22 and follows the same exponential decreases with successive leaches. Leachates showed a large variability in their colour, and visual observation after particle settling showed that they contained a large number of very fine particles even in the $<0.2 \mu \mathrm{m}$ fraction. Blank concentrations for exposure blank and procedural blank filters averaged $\sim 0.4 \pm 0.06$ and $0.5 \pm 0.01 \mathrm{ng} \mathrm{g}^{-1}$ of soluble Fe respectively.

\subsubsection{Total trace element concentrations}

Total $\mathrm{PM}_{10}$ trace element $(\mathrm{Na}, \mathrm{Al}, \mathrm{K}, \mathrm{Ti}, \mathrm{V}, \mathrm{Cr}, \mathrm{Mn}, \mathrm{Fe}$, $\mathrm{Mo}, \mathrm{Pb}, \mathrm{As}$ ) concentrations were determined following recommendations from the 2008 GEOTRACES intercalibration experiment for the analysis of marine aerosols (Morton et al., 2013). Details for $\mathrm{HNO}_{3}$ and $\mathrm{HF}$ acid digestion of filter samples and certified reference materials (MESS-3 marine sediment from the National Research Council, Canada, and QC-TMFM-A-spiked trace metals $(1-10 \mu \mathrm{g}$ of trace metal per filter) on nitrocellulose filter (TMF) from High-Purity Standards) can be found in Winton et al. (2016a). Recovery rates for elements are reported in Table S2 in the Supplement. Blank concentrations for Savillex ${ }^{\circledR}$ digestion beakers, exposure blank, procedural blank, and laboratory blank filters averaged $\sim 4 \pm 3 \mathrm{ng} \mathrm{g}^{-1}(n=3), \sim 150 \pm 8 \mathrm{ng} \mathrm{g}^{-1}(n=2)$, $\sim 140 \pm 30 \mathrm{ng} \mathrm{g}^{-1}(n=4)$, and $\sim 140 \pm 90 \mathrm{ng} \mathrm{g}^{-1}(n=6)$ of total Fe respectively. The non-sea-salt potassium (nss-K) fraction of total $\mathrm{K}$ was obtained by subtracting the contribution of sea-salt-derived $\mathrm{K}$ from the measured $\mathrm{K}$ concentrations $(\mathrm{nss}-\mathrm{K}=\mathrm{K}-0.037 \times \mathrm{Na}$, where $\mathrm{Na}$ and $\mathrm{K}$ are the measured concentrations in aerosol samples and 0.037 is the $\mathrm{K} / \mathrm{Na}$ ratio in sea salt (Keene et al., 1986).

\subsubsection{High-resolution inductively coupled plasma mass spectrometry analysis}

Leachates and resuspended total digests were analysed by high-resolution inductively coupled plasma mass spectrometry (HR-ICP-MS, Element XR Thermo Fisher) at Curtin University following Winton et al. (2016a). All samples and standards were prepared on a similar matrix basis. During the course of the sample sequence, an EPA standard (cat. \#ICP200.7-6 Solution A, High-Purity Standards) was measured regularly for quality control. Laboratory vial blanks, also measured regularly during the course of the sample sequence, were determined by carrying out identical analytical procedures as the leachates but vials were filled with ultrapure water rather than the leachate. Leachate concentrations were corrected for laboratory blanks, and the total digest concentrations corrected for the Savillex ${ }^{\circledR}$ digestion beaker blanks. Measured trace elements and the spectral resolutions, along with typical operating conditions, are reported in Table S3 in the Supplement.

\subsection{Air mass back trajectories}

To identify the source region of air masses arriving at Gunn Point, we used hourly 5-day $(120 \mathrm{~h})$ back trajectories (ending at $12 \mathrm{~m}$ a.g.1.) to reconstruct atmospheric circulation leading up to, and during, individual events. Air mass back trajectories were produced using the "HYSPLIT4" program based on the NOAA ARL HYbrid Single-Particle Lagrangian Integrated Trajectory (HYSPLIT) model (Draxler and Rolph, 2003) (http://ready.arl.noaa.gov/HYSPLIT.php). Global Data Assimilation System (GDAS) model files obtained from NOAA ARL FTP (http://ready.arl.noaa.gov/ gdas1.php) were used to drive the model. The resolution used was $1^{\circ}$.

\subsection{Radon concentrations}

Natural radioactive noble gas ${ }^{222} \mathrm{Rn}$ (radon) is a useful quantitative indicator of diurnal to synoptic scale mixing processes within the continental lower troposphere (Chambers et al., 2015), and a suitable tracer for continental air (e.g. Dörr et al., 1983). This is because radon has a half-life of 3.8 days and only one source and sink - i.e. radon is solely produced from terrestrial surfaces and is lost from the atmosphere by radioactive decay. The ANSTO-built $700 \mathrm{~L}$ dualflow-loop two-filter radon detector (e.g. Whittlestone and Zahorowski, 1998; Chambers et al., 2014) samples air from 12 $\mathrm{m}$ above ground level (a.g.l.). A coarse aerosol filter and dehumidifier are installed "upstream" of the detector, as well as a $400 \mathrm{~L}$ delay volume to ensure that thoron $\left({ }^{220} \mathrm{Rn}\right.$, half-life $55 \mathrm{~s}$ ) concentrations in the inlet air stream are reduced to less than $0.5 \%$ of their ambient values. The detector's response time is around $45 \mathrm{~min}$, and its lower limit of determination is $40-50 \mathrm{mBq} \mathrm{m}^{-3}$. Calibrations are performed on a monthly basis by injecting radon from a PYLON $101.15 \pm 4 \% \mathrm{kBq}$ ${ }^{226} \mathrm{Ra}$ source $\left(12.745 \mathrm{~Bq} \mathrm{~min}^{-1222} \mathrm{Rn}\right)$, traceable to NIST standards, and instrumental background is checked every 3 months. The time series from the Gunn Point campaign has been separated into (a) advective contributions (essentially afternoon-to-afternoon interpolated values, reflecting the air mass fetch history over the last two weeks) and (b) diurnal variability (the residual, indicative of change in mixing depth) following the method of Chambers et al. (2015).

\subsection{Oxalate and levoglucosan}

Oxalate and levoglucosan measurements were performed on the $\mathrm{PM}_{10}$ quartz filters at CSIRO Ocean and Atmo- 
sphere. The filters were Pall Tissuquartz filters (p/n 7204), baked at $600^{\circ} \mathrm{C}$ for $4-8 \mathrm{~h}$ before use and stored frozen after sampling until analysis. A $6.25 \mathrm{~cm}^{2}$ section was cut out of the filter and extracted in $5 \mathrm{~mL}$ of ultra-pure water. The quartz filter extracts were analysed for major water-soluble ions by suppressed ion chromatography (IC) and for anhydrous sugars, including levoglucosan, by high-performance anion-exchange chromatography with pulsed amperometric detection (HPAEC-PAD) (Iinuma et al., 2009; Hibberd et al., 2013). Three exposure blanks were analysed alongside the sample filters. The oxalate blank, calculated using an average collection volume of $1575 \mathrm{~m}^{3}$, was $0.0009 \mu \mathrm{g} \mathrm{m}^{-3}$ with a method detection limit (MDL) of $0.0002 \mu \mathrm{g} \mathrm{m}^{-3}$. While levoglucosan had no detectable blank with a MDL of $0.00002 \mu \mathrm{g} \mathrm{m}^{-3}$. All sample concentrations were blankcorrected.

\subsection{Elemental carbon}

Elemental carbon analysis was performed on the $\mathrm{PM}_{10}$ quartz filters at CSIRO Ocean and Atmosphere using a DRI model 2001A thermal-optical carbon analyser following the IMPROVE-A temperature protocol (Chow et al., 2007). We note that the difference in the terminology of black carbon versus elemental carbon in the literature reflects the characteristics of carbonaceous matter and the analytical method employed (Andreae and Gelencsér, 2006; Petzold et al., 2013; Bond et al., 2013). The terminology used here follows that recommended by Petzold et al. (2013) - i.e. the term "black carbon" is used qualitatively when referring to material that shares some of the characteristics of black carbon (carbonaceous composition combined with light-absorbing properties), "elemental carbon" refers to data derived from methods that are specific to the carbon content of carbonaceous matter using thermal desorption methods, "refractory black carbon" (rBC) is used instead of black carbon for measurements derived from incandescence methods, and mixed particles containing black carbon are referred to as "blackcarbon-containing particles". The data reported in this study were analysed using thermal desorption methods and are referred to as elemental carbon.

\section{Results}

\subsection{Air mass back trajectories}

We identified predominate fetch regions that gave rise to particular events: (a) "inland, low population density", (b) "coastal, moderate urban/industrial activity", (c) "major urban/industrial activity", and (d) "southerly". The mean trajectory for each group was calculated, and these representative trajectories are indicated in Fig. 1.

\subsection{Biomass burning events during the campaign}

The campaign was heavily influenced by thousands of proximal wild and prescribed bushfires (Milic et al., 2016). A number of biomass burning markers were used to identify major burn events during the campaign, including carbon monoxide (CO), levoglucosan, oxalate, and elemental carbon (Figs. 3-6) (Milic et al., 2016; Desservettaz et al., 2016; Mallet et al., 2016). Nine burn events were identified, with three intense episodes occurring on 9 June (fire event "E"), 25 June (fire event "FG"), and 26-27 June 2014 (fire event "HI) (see Desservettaz et al., 2016, for a description of the fire events). Smoke transported to the ATARS during fire event "E" comprised both distally sourced fires, i.e. $>200 \mathrm{~km}$, and locally sourced fires, i.e. within $5 \mathrm{~km}$ (Mallet et al., 2016). Fire locations were obtained from the Sentinel Hotspot system (MODIS and VIIRS satellites) (Milic et al., 2016). However, the sources of emissions for the largest fire events, "FG" and "HI", were proximal, i.e. within $10 \mathrm{~km}$ of the ATARS. These high intensity fire events were accompanied by smouldering burning conditions that resulted in high organic loadings and high levoglucosan concentrations. Due to the different time periods the $\mathrm{CO}$ data (minute) and aerosol samples (daily) integrate, we have grouped fire events " $F$ " and "G" into one event (fire event "FG") and "H" and "I" into another event (fire event "HI") for this study. In addition, concentrations of nss-K and nss-K normalised relative to other elemental concentration are good indicators of biomass burning (Yamasoe et al., 2000; Maenhaut et al., 2002). There is good agreement between nss-K concentrations and $\mathrm{CO}\left(r^{2}=0.55\right)$ (Fig. S2 in the Supplement). There is also a good correlation between nss-K and elemental carbon concentrations $\left(r^{2}=0.74\right)$ (Fig. S2 in the Supplement). Following Guieu et al. (2005), we normalise nss-K to $\mathrm{Fe}$ and compare the ratio to crustal aerosols (nss- $\mathrm{K} / \mathrm{Fe}=0.49$; Wedepohl, 1995) and polluted aerosols (nss-K $/ \mathrm{Fe}=0.27$; urban particulate matter - standard reference \#1648, NIST). During the campaign the nss- $\mathrm{K} / \mathrm{Fe}$ ratio ranged between 0.2 and 4.9. This relativity large range was similar to nss- $\mathrm{K} / \mathrm{Fe}$ of $0.63-1.8$ for Mediterranean summer fires in 2003 (Guieu et al., 2005), nss-K / Fe of 2.0 for biomass burning aerosols for the Arabian Sea and the Bay of Bengal (Srinivas et al., 2012), and nss-K / Fe of 0.51 for the West African Sahel biomass burning (Paris et al., 2010). These studies suggested that the higher ratio reflected a primarily fire origin for nss-K. The nss-K / Fe ratio was especially high during the three fire events in this study (nss- $\mathrm{K} / \mathrm{Fe} \sim 4$ ) and during high elemental carbon concentrations between 21 and 27 June (nss-K / Fe 2.2) compared to non-fire events (nss- $\mathrm{K} / \mathrm{Fe} \sim 1.3$ ). Even the lowest nss$\mathrm{K} / \mathrm{Fe}$ of 1.3 during the campaign is particularly high compared to crustal aerosols. This relatively high ratio suggests that, even at times when there are no major fire events, background biomass burning during the Australian dry season is a stronger emitter of $\mathrm{K}$ than of $\mathrm{Fe}$ and emits relatively little of other trace elements. 
(a)
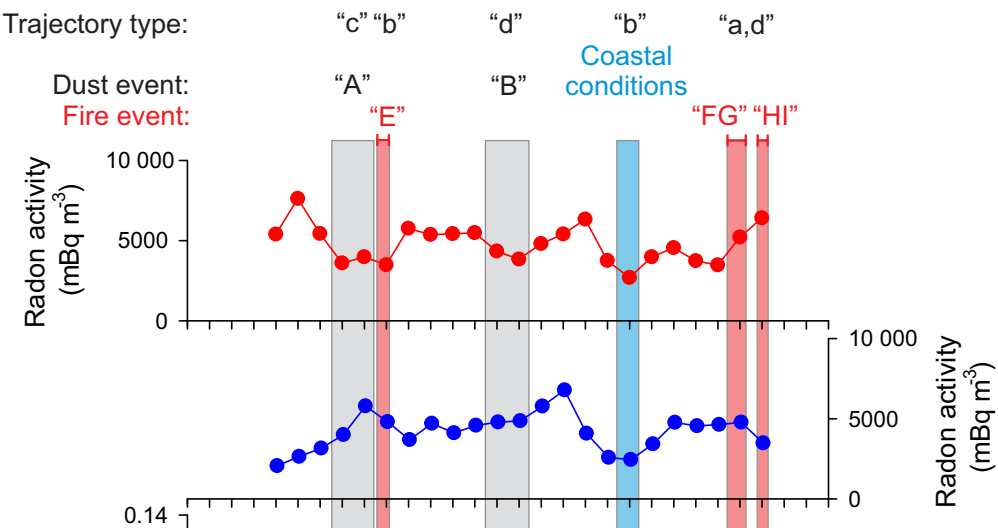

(c)

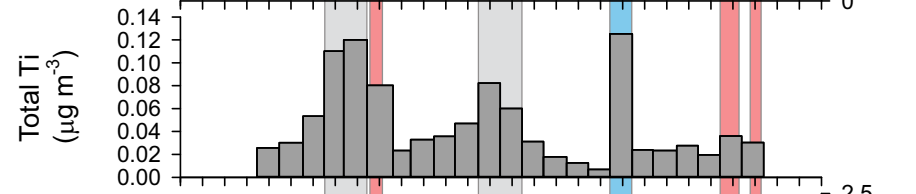

(d)

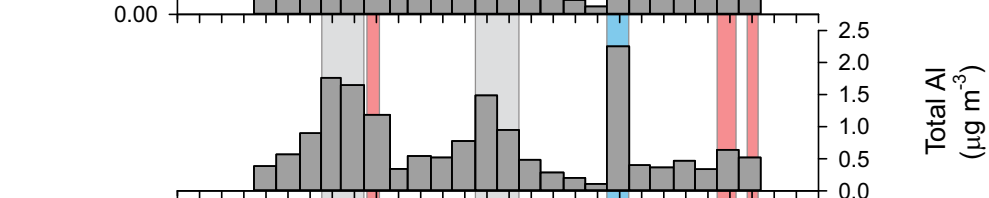

(e)

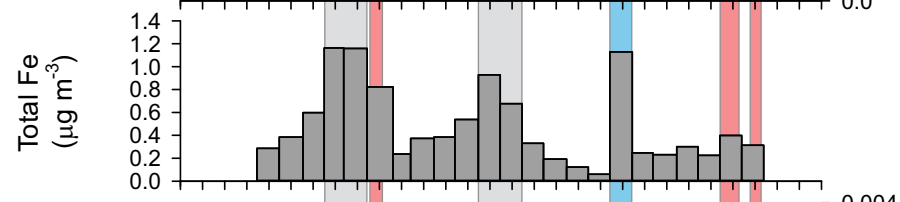

(f)

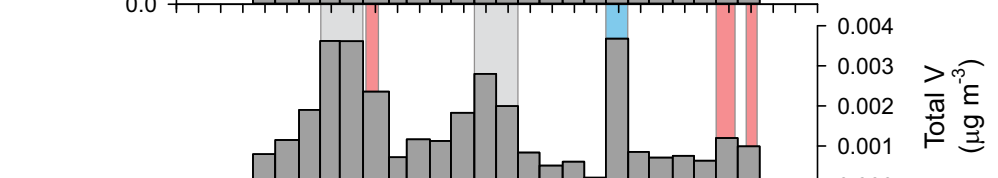

(g)

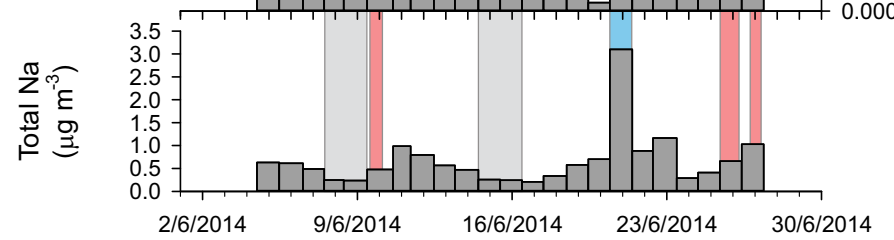

Figure 3. Composition of daily aerosol samples influenced by dry season biomass burning at Gunn Point, northern Australia. The time series highlights markers indicative of mineral dust (a) diurnal radon; (b) advective radon; and $\mathrm{PM}_{10}$ trace element concentrations of (c) total Ti, (d) total $\mathrm{Al}$, (e) total Fe, (f) total V, and (g) total Na. Fire events, dust events and coastal conditions are highlighted. For trajectory types associated with these periods refer to Fig. 1.

\subsection{Trace element mass concentrations}

Total and soluble $\mathrm{PM}_{10}$ trace element concentrations are illustrated in Figs. 3-5 and the data set is available in Winton et al. (2015b). Total $\mathrm{PM}_{10}$ aerosol $\mathrm{Fe}$ ranges from 60 to $1164 \mathrm{ng} \mathrm{m}^{-3}$, while soluble aerosol $\mathrm{Fe}$ ranges from 7 to $141 \mathrm{ng} \mathrm{m}^{-3}$. A strong linear correlation was found between the total $\mathrm{PM}_{10}$ trace elements of $\mathrm{Fe}, \mathrm{Al}, \mathrm{V}$ and Ti, i.e. total $\mathrm{Fe}$ and total $\mathrm{Al}\left(r^{2}=0.96\right)$, total $\mathrm{Fe}$ and total $\mathrm{Ti}\left(r^{2}=0.98\right)$, and total $\mathrm{Fe}$ and total $\mathrm{V}\left(r^{2}=0.99\right)$ (Figs. 3 and S3 in the Supplement). Likewise, a strong linear correlation between the soluble trace elements of $\mathrm{Fe}, \mathrm{Al}$, and $\mathrm{Ti}$ was found during the campaign (Figs. 5 and S3 in the Supplement), i.e. soluble $\mathrm{Fe}$ and soluble $\mathrm{Al}\left(r^{2}=0.97\right)$ and soluble $\mathrm{Fe}$ and sol- uble $\mathrm{Ti}\left(r^{2}=0.86\right)$. There is considerable temporal variability in soluble and total trace elements throughout the campaign. Two distinct events in soluble $\mathrm{Al}, \mathrm{Ti}$, and $\mathrm{Fe}$ and total $\mathrm{Al}, \mathrm{Ti}, \mathrm{V}$, and $\mathrm{Fe}$ are observed on 7-8 June 2014 (GP4-5; $78-141 \mathrm{ng} \mathrm{m}^{-3}$ of soluble $\mathrm{Fe}$ and $1158-1164 \mathrm{ng} \mathrm{m}^{-3}$ of total $\mathrm{Fe}$ ), and 14-15 June 2014 (GP11-12; 52-92 $\mathrm{ng} \mathrm{m}^{-3}$ of soluble $\mathrm{Fe}$ and $677-928 \mathrm{ng} \mathrm{m}^{-3}$ of total Fe) (Figs. 3 and 5). On 20 June 2014, high concentrations of these crustal-like elements (total and soluble $\mathrm{Al}, \mathrm{Ti}, \mathrm{V}, \mathrm{Fe}$ ) were also observed (GP17; $67 \mathrm{ng} \mathrm{m}^{-3}$ of soluble Fe and $1129 \mathrm{ng} \mathrm{m}^{-3}$ of total $\mathrm{Fe}$ ) and are associated with coastal air masses (Fig. 1; trajectory type "b"). Total $\mathrm{Cr}$, As, Mo, V, and $\mathrm{Na}$ also peaked during coastal conditions (Fig. 5). During the fire event "E" 
(a)

(b)

$\begin{array}{rlll}\text { Trajectory type: } & \text { "c" "b" } & \text { "d" } & \begin{array}{c}\text { "b" } \\ \text { Coastal }\end{array} \\ \text { Dust event: } & \text { "A" } & \text { "B" } & \text { conditions }\end{array}$

(a)

Fire event:

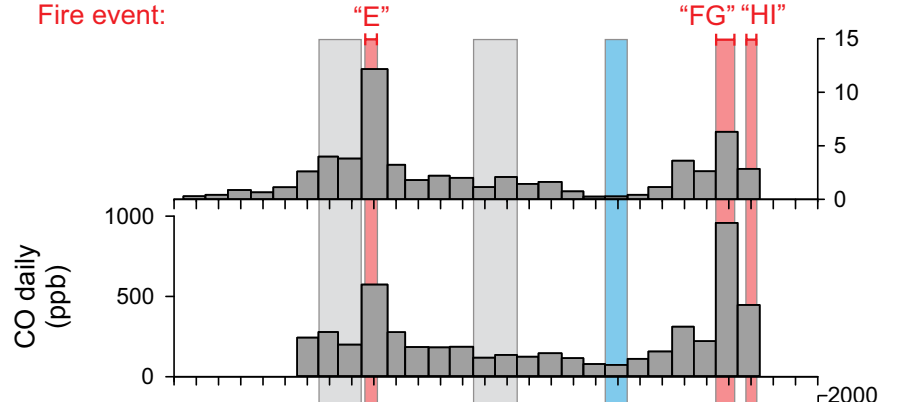

(c)

(d)

簿量

(e)

(f)

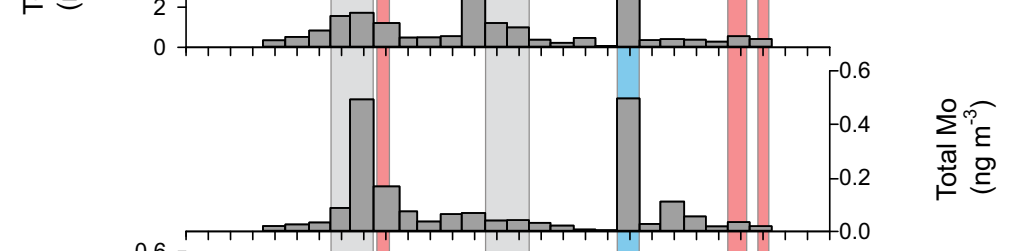

(g)

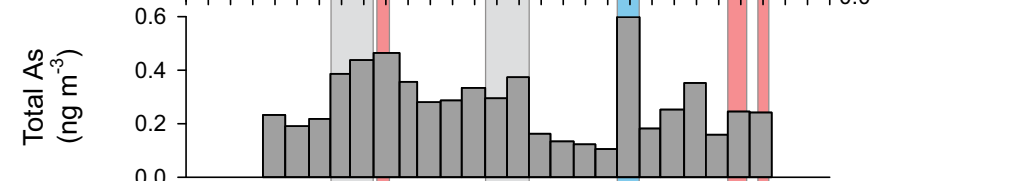

(h)

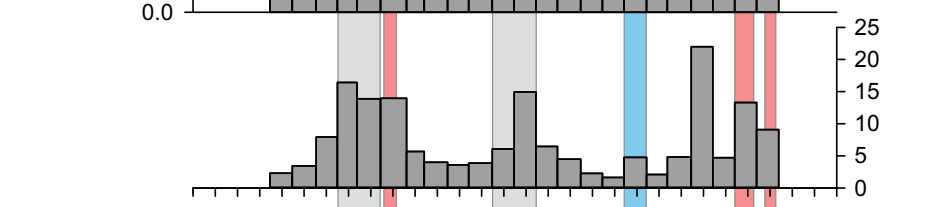

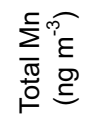

(i)

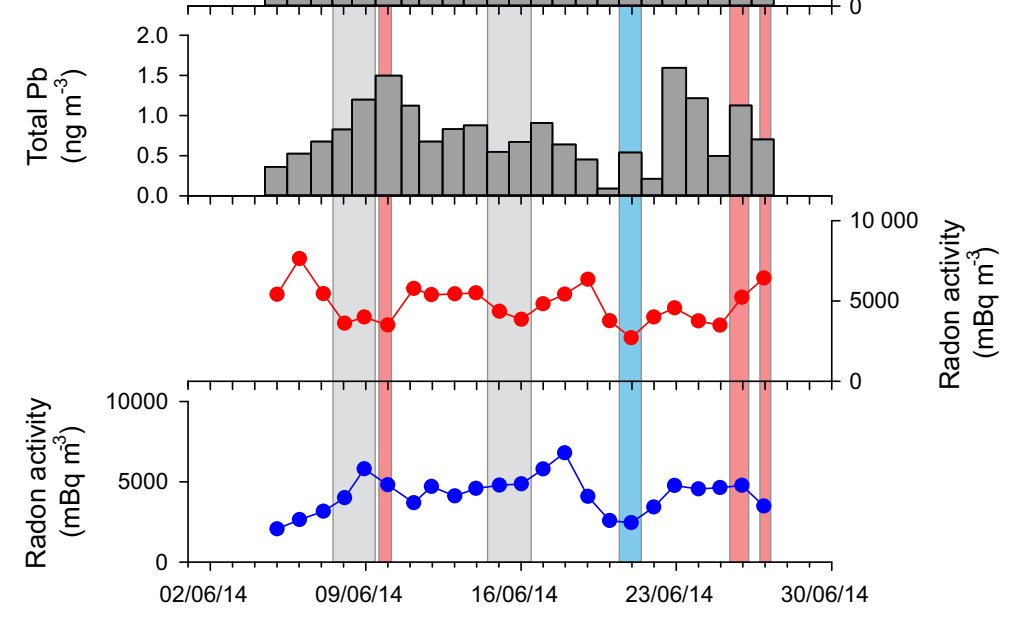

Figure 4. Total trace metal composition of daily aerosol samples influenced by dry season biomass burning at Gunn Point, northern Australia. Time series of (a) elemental carbon concentration; (b) carbon monoxide concentration; $\mathrm{PM}_{10}$ trace element concentrations of (c) total nss-K, (d) total $\mathrm{Cr}$, (e) total $\mathrm{Mo}$, (f) total $\mathrm{As}$, (g) total $\mathrm{Mn}$, and (h) total $\mathrm{Pb}$; and (i) diurnal radon and (j) advective radon. Fire events, dust events and coastal conditions are highlighted. For trajectory types associated with these periods refer to Fig. 1. 
(a)

(b)

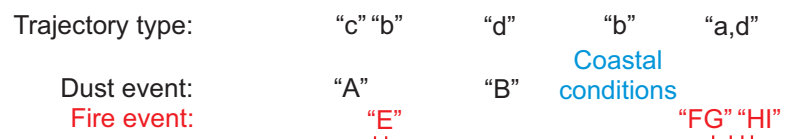

(c)

(d)

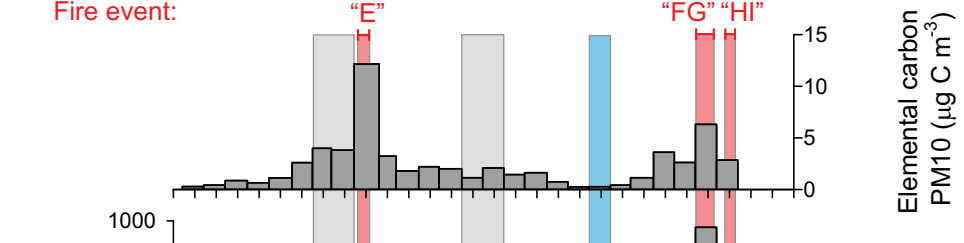

(e)

(f)

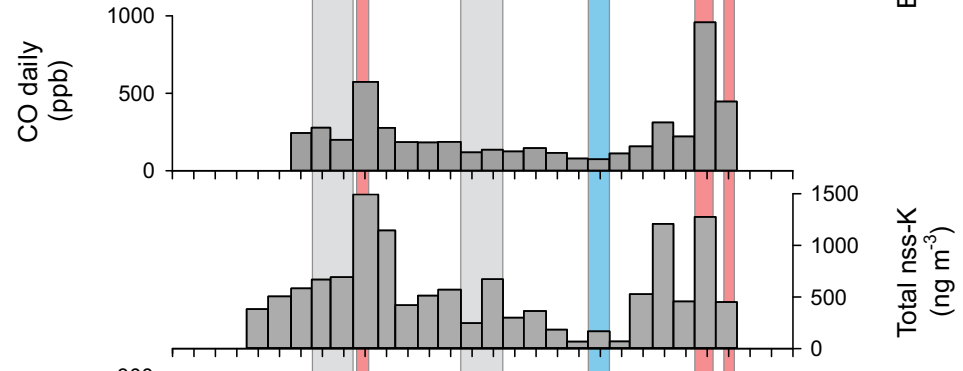

(g)

(h)

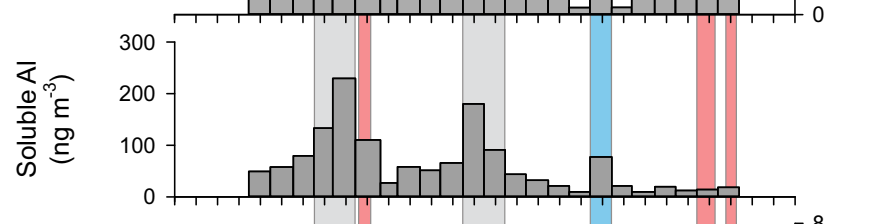

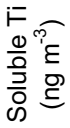

(i)

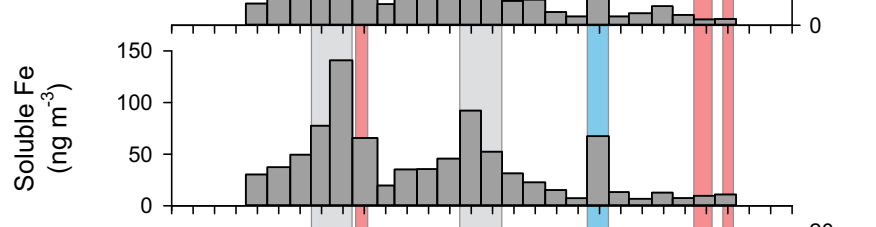

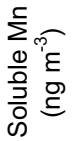

(j)

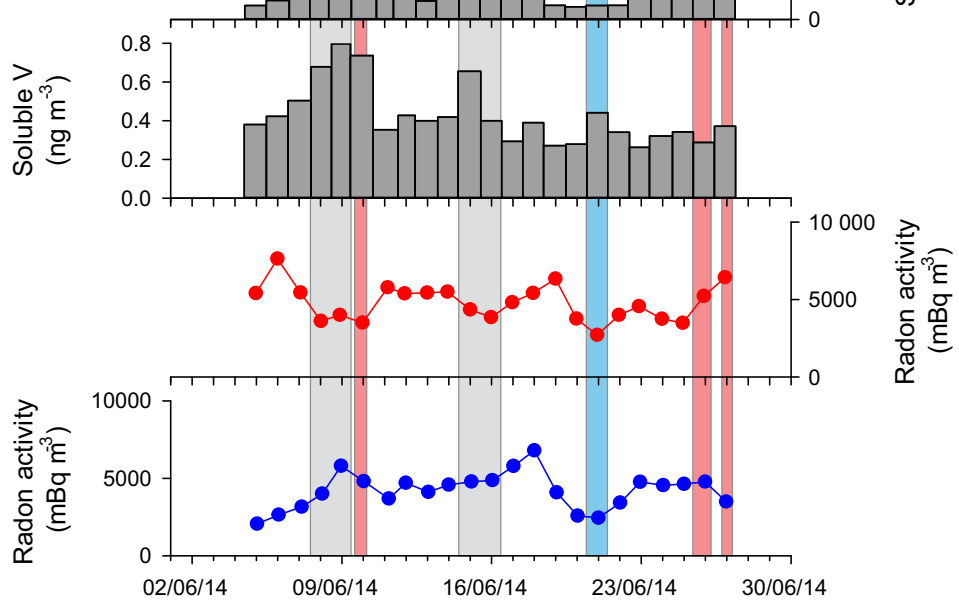

Figure 5. Soluble trace metal composition of daily aerosol samples influenced by dry season biomass burning at Gunn Point, northern Australia. Time series of (a) elemental carbon concentration; (b) carbon monoxide concentration; $\mathrm{PM}_{10}$ trace element concentrations of (c) total nss-K, (d) soluble Al, (e) soluble Ti, (f) soluble Fe, (g) soluble Mn, and (h) soluble V; and (i) diurnal radon and (j) advective radon. Fire events, dust events and coastal conditions are highlighted. For trajectory types associated with these periods refer to Fig. 1. 


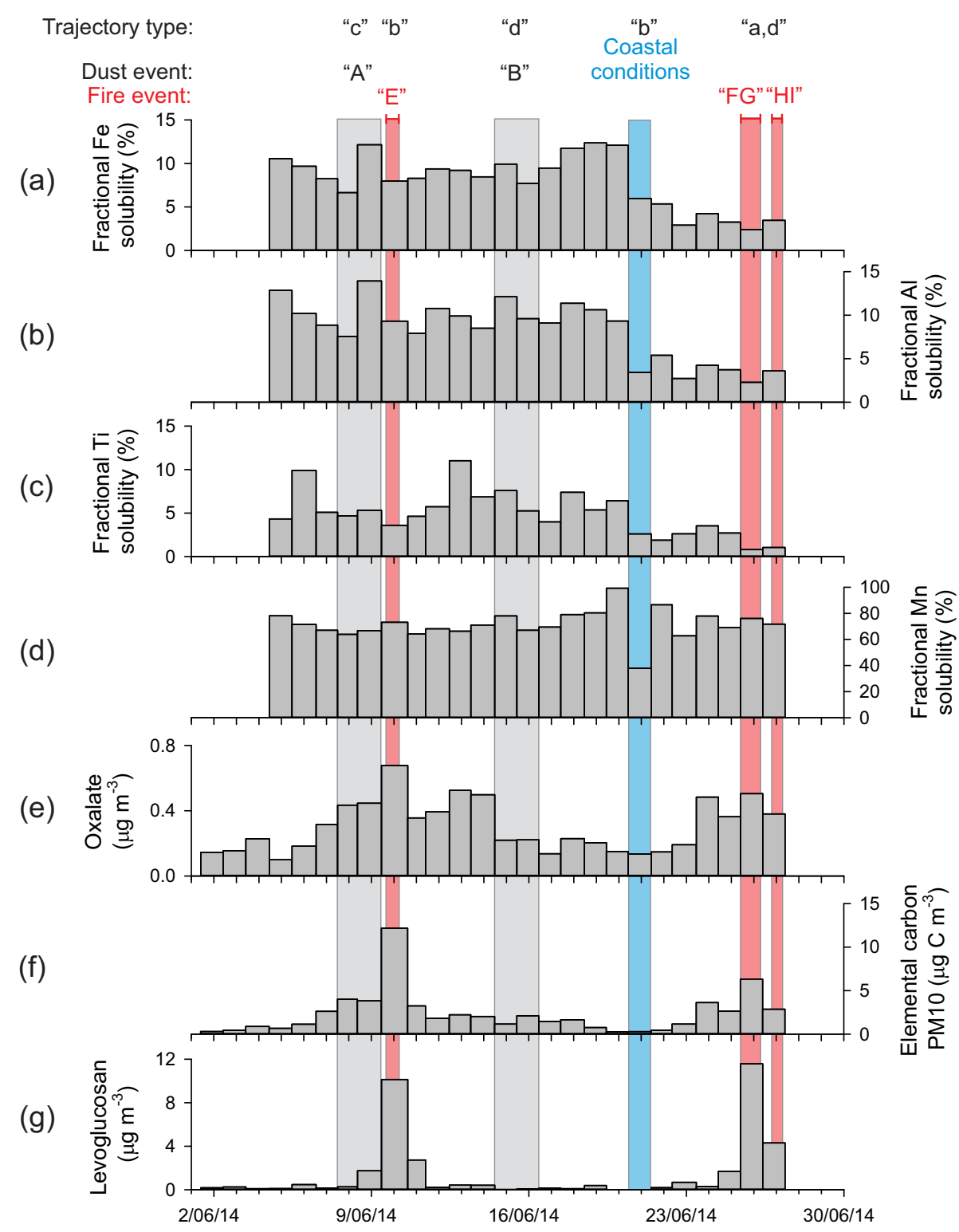

Figure 6. Composition of daily aerosol samples influenced by dry season biomass burning at Gunn Point, northern Australia. The time series highlights markers indicative of biomass burning and the associated trace metal fractional solubility (a) fractional Fe solubility, (b) fractional Al solubility, (c) fractional Ti solubility, (d) fractional Mn solubility, (e) oxalate concentration, (f) elemental carbon concentration, and (g) levoglucosan concentration. Fire events, dust events and coastal conditions are highlighted. For trajectory types associated with these periods refer to Fig. 1.

on 9 June, total $\mathrm{As}, \mathrm{Mn}$, and $\mathrm{Pb}$ concentrations were high (Fig. 4).

\subsection{Dry deposition iron flux}

Estimates of the $\mathrm{Fe}$ dry deposition rate $\left(F_{\mathrm{dry}}\right)$ to adjacent north Australian surface waters were calculated using Eq. (1) and the total and soluble Fe concentrations $\left(C_{\text {aerosol }}\right)$ reported from this study. We apply a dry deposition velocity $\left(V_{\text {dry }}\right)$ of $2 \mathrm{~cm} \mathrm{~s}^{-1}$ for coastal areas (Duce et al., 1991) following Baker et al. (2003) for aerosols collected along a transect in the At- lantic Ocean and Baker et al. (2007) for the atmosphere over the tropical Atlantic Ocean. Estimates of Fe dry deposition rates for Gunn Point aerosols are reported in Table 1.

$F_{\text {dry }}=C_{\text {aerosol }} \times V_{\text {dry deposition }}$ 
Table 1. Aerosol iron concentrations and dry deposition fluxes for Gunn Point $\mathrm{PM}_{10}$ aerosols.

\begin{tabular}{|c|c|c|c|c|c|c|c|c|}
\hline Sample & $\begin{array}{l}\text { Soluble Fe } \\
\text { concentration } \\
\left(\mathrm{ng} \mathrm{m}^{-3}\right)\end{array}$ & \pm & $\begin{array}{l}\text { Soluble Fe flux } \\
\left(\mu \mathrm{mol} \mathrm{m}{ }^{-2} \mathrm{day}^{-1}\right)^{*}\end{array}$ & \pm & $\begin{array}{l}\text { Total Fe } \\
\text { concentration } \\
\left(\mathrm{ng} \mathrm{m}^{-3}\right)\end{array}$ & \pm & $\begin{array}{l}\text { Total Fe flux } \\
\left(\mu \mathrm{mol} \mathrm{m}{ }^{-2} \mathrm{day}^{-1}\right)^{*}\end{array}$ & \pm \\
\hline GP1 & 30 & 2 & 0.9 & 1.9 & 286 & 9 & 9 & 18 \\
\hline GP2 & 37 & 1 & 1.1 & 2.3 & 384 & 12 & 12 & 24 \\
\hline GP3 & 49 & 2 & 1.5 & 3.1 & 598 & 19 & 18 & 37 \\
\hline GP4 & 78 & 3 & 2.4 & 4.8 & 1164 & 37 & 36 & 72 \\
\hline GP5 & 140 & 6 & 4.3 & 8.7 & 1158 & 37 & 36 & 71 \\
\hline GP6 & 66 & 3 & 2.0 & 4.1 & 823 & 26 & 25 & 51 \\
\hline GP7 & 20 & 0.8 & 0.6 & 1.2 & 236 & 7 & 7 & 15 \\
\hline GP8 & 35 & 1 & 1.1 & 2.2 & 374 & 12 & 12 & 23 \\
\hline GP9 & 35 & 1 & 1.1 & 2.2 & 385 & 12 & 12 & 24 \\
\hline GP10 & 46 & 2 & 1.4 & 2.8 & 539 & 17 & 17 & 33 \\
\hline GP11 & 92 & 4 & 2.8 & 5.7 & 928 & 29 & 29 & 57 \\
\hline GP12 & 52 & 2 & 1.6 & 3.2 & 677 & 21 & 21 & 42 \\
\hline GP13 & 31 & 1 & 1.0 & 1.9 & 331 & 10 & 10 & 20 \\
\hline GP14 & 23 & 0.9 & 0.7 & 1.4 & 192 & 6 & 6 & 12 \\
\hline GP15 & 15 & 0.6 & 0.5 & 0.9 & 123 & 4 & 4 & 8 \\
\hline GP16 & 7 & 0.3 & 0.2 & 0.5 & 60 & 2 & 2 & 4 \\
\hline GP17 & 67 & 3 & 2.1 & 4.2 & 1129 & 36 & 35 & 70 \\
\hline GP18 & 13 & 0.5 & 0.4 & 0.8 & 247 & 8 & 8 & 15 \\
\hline GP19 & 7 & 0.3 & 0.2 & 0.4 & 231 & 7 & 7 & 14 \\
\hline GP20 & 13 & 0.5 & 0.4 & 0.8 & 301 & 10 & 9 & 19 \\
\hline GP21 & 7 & 0.3 & 0.2 & 0.5 & 225 & 7 & 7 & 14 \\
\hline GP22 & 10 & 0.4 & 0.3 & 0.6 & 399 & 13 & 12 & 25 \\
\hline GP23 & 11 & 0.4 & 0.3 & 0.7 & 314 & 10 & 10 & 19 \\
\hline
\end{tabular}

* The uncertainty in dry deposition fluxes was calculated by propagation of error of the analytical uncertainty and uncertainty in the deposition velocity, which is assumed to be a factor of 2-3 (Baker et al., 2003; Duce et al., 1991).

\section{Discussion}

\subsection{Iron mass concentrations}

The soluble Fe concentrations of $7-141 \mathrm{ng} \mathrm{m}^{3}$ at Gunn Point are less than soluble Fe concentrations reported in smoke from the Mediterranean and West African Sahel $\left(350 \mathrm{ng} \mathrm{m}^{3}\right)$ (Guieu et al., 2005) and (130 $\mathrm{ng} \mathrm{m}^{3}$ ) (Paris et al., 2010) respectively. There are sparse total and soluble aerosol Fe concentration data for Australian aerosols; however, our estimates of total $\mathrm{Fe}\left(60-1160 \mathrm{ng} \mathrm{m}^{3}\right.$; Fig. 3) agree with reported total $\mathrm{Fe}$ concentrations at Jabiru, northern Australia $\left(148 \mathrm{ng} \mathrm{m}^{-3}\right)$, at Sydney, New South Wales $\left(150 \mathrm{ng} \mathrm{m}^{-3}\right)$, and modelled values for the north Australia coastal area (200-1000 $\mathrm{ng} \mathrm{m}^{-3}$ ) (Mahowald et al., 2009, and references within). Compared to aerosol Fe from other tropical regions, our total Fe estimates from Australia are in good agreement with biomass burning aerosol studies reported from Alta Floresta, Brazil, between 1996 and 1998, which range from 300 to $1200 \mathrm{ng} \mathrm{m}^{-3}$ of total Fe (Maenhaut et al., 2002). Total Fe concentrations decrease from the source to the open ocean; for example, aerosol $\mathrm{Fe}$ concentrations reported for the tropical Atlantic open ocean range from 6 to $56 \mathrm{ng} \mathrm{m}^{-3}$ for total $\mathrm{Fe}$ and 6 to $28 \mathrm{ng} \mathrm{m}^{-3}$ for soluble Fe (Baker et al., 2006).

\subsection{Dry deposition estimates of soluble and total iron}

Estimates of soluble and total $\mathrm{PM}_{10} \mathrm{Fe}$ dry deposition fluxes are reported in Table 1 and range from $0.2 \pm 0.4$ to $4 \pm 9 \mu \mathrm{mol} \mathrm{m}^{-2} \mathrm{day}^{-1}$ for soluble $\mathrm{Fe}$ and $2 \pm 4$ to $36 \pm 72 \mu \mathrm{mol} \mathrm{m}^{-2} \mathrm{day}^{-1}$ for total $\mathrm{PM}_{10} \mathrm{Fe}$. The dry deposition Fe estimates for air over Gunn Point are compared to other aerosol studies from the Southern Hemisphere and tropical regions. The mean soluble Fe dry deposition flux $\left(\sim 1 \mu \mathrm{mol} \mathrm{m}{ }^{-2}\right.$ day $\left.^{-1}\right)$ is greater than soluble $\mathrm{Fe}$ dry deposition fluxes over open-ocean tropical Atlantic waters $\left(0.01-0.1 \mu \mathrm{mol} \mathrm{m}{ }^{-2}\right.$ day $^{-1}$ ) (Baker et al., 2003). The estimates at Gunn Point are also higher than those reported for the Southern Ocean, for example $0.002-0.007 \mu \mathrm{mol} \mathrm{m}^{-2} \mathrm{day}^{-1}$ reported by Bowie et al. (2009), $0.001-0.003 \mu \mathrm{mol} \mathrm{m}{ }^{-2}$ day $^{-1}$ reported by Wagener et al. (2008), 0.002-0.007 $\mathrm{mmol} \mathrm{m}^{-2} \mathrm{day}^{-1}$ reported by Baker et al. (2013) for the South Atlantic, and 0.001$0.007 \mu \mathrm{mol} \mathrm{m}^{-2}$ day $^{-1}$ for baseline air over the Southern Ocean reported by Winton et al. (2015a). Estimates of total $\mathrm{PM}_{10} \mathrm{Fe}$ dry deposition fluxes at Gunn Point are higher than those for the Southern Ocean (0.001$0.12 \mu \mathrm{mol} \mathrm{m}^{-2} \mathrm{day}^{-1}$ ) (Winton et al., 2015a) and the South 


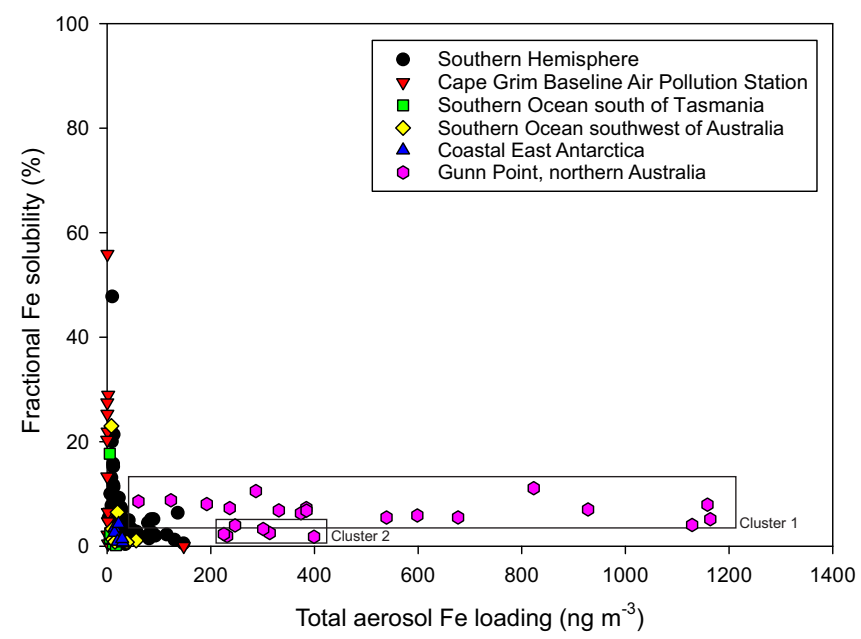

Figure 7. Gunn Point total $\mathrm{PM}_{10}$ aerosol iron mass concentration versus fractional Fe solubility superimposed on the Southern Hemispheric aerosol iron data set (Sholkovitz et al., 2012, and references within; Bowie et al., 2009; Gao et al., 2013; Winton et al., 2015a). Boxes highlight the two clusters. Cluster 1: moderate fractional $\mathrm{Fe}$ solubility and moderate total aerosol iron loading between 4 and 19 June. This cluster represents the upper bound of dust fractional Fe solubility of mixed mineral dust and biomass-burning-derived particles in the topical dry season. Cluster 2: low fractional Fe solubility and low total aerosol iron loading between 24 and 26 June, i.e. intense proximal biomass burning.

Atlantic (0.1-0.3 $\left.\mu \mathrm{mol} \mathrm{m}^{-2} \mathrm{day}^{-1}\right)$ (Baker et al., 2013). The Gunn Point data are in good agreement with estimates from global models for the northern Australian coastal region. Mahowald et al. (2009) estimate total $\mathrm{Fe}$ deposition in northern Australia to be $0.04-1 \mathrm{~g} \mathrm{~m}^{-2} \mathrm{yr}^{-1}$, and our mean total $\mathrm{PM}_{10}$ Fe flux of $0.3 \mathrm{~g} \mathrm{~m}^{-2} \mathrm{yr}^{-1}$ falls within this range.

\subsection{Fractional iron solubility}

The fractional Fe solubility ranged from 2 to $12 \%$ during the study (Figs. 6 and 7). These estimates are within the 0.6 to $40 \%$ range of fractional $\mathrm{Fe}$ solubility reported for biomass burning (Paris et al., 2010; Bowie et al., 2009; Ito, 2011, 2015; Guieu et al., 2005). Fractional Fe solubility was highest between 4 and 20 June, with a mean fractional Fe solubility of $10 \pm 2 \%$. After 20 June, the fractional Fe solubility dropped to $3 \pm 1 \%$ between 21 and 27 June, when fires were proximal to the ATARS. These trends in fractional Fe solubility over the campaign are not unique to $\mathrm{Fe}$; the variation in fractional $\mathrm{Al}$ and Ti solubility paralleled that of fractional Fe solubility (Fig. 6). During dust event "A" (see Sect. 4.5.1) fractional Fe solubility peaked at $\sim 12 \%$, fractional Al solubility at $\sim 14 \%$, and fractional Ti solubility at $\sim 5 \%$ (Fig. 6 ). Fractional $\mathrm{Al}$ and $\mathrm{Ti}$ solubility also decreased on 24 June from $10 \pm 2$ to $3 \pm 1 \%$ for $\mathrm{Al}$ and from $6 \pm 2$ to $2 \pm 1 \%$ for Ti (Fig. 6). On the other hand, fractional Mn solubility was relatively high and constant throughout the campaign and av- eraged $\sim 72 \pm 11 \%$. The factors that regulate fractional $\mathrm{Fe}$ solubility in these samples may also regulate the solubility of $\mathrm{Al}$ and $\mathrm{Ti}$ but not $\mathrm{Mn}$.

A synthesis of global aerosol Fe solubility data sets, complied by Sholkovitz et al. (2012), displayed an inverse hyperbolic relationship between the total $\mathrm{Fe}$ concentration and fractional Fe solubility (Fig. 7). This characteristic relationship is common over large regions of the global ocean, and has been attributed to the mixing of mineral dust with a low $\mathrm{Fe}$ solubility and other soluble $\mathrm{Fe}$ aerosols from combustion sources (e.g. Sedwick et al., 2007). We have plotted the Gunn Point aerosol Fe data with the Southern Hemisphere compilation in Fig. 7. Our data sit within two clusters: (i) moderate fractional Fe solubility and high total $\mathrm{PM}_{10}$ aerosol Fe loading between 4 and 19 June and (ii) low fractional Fe solubility and moderate total $\mathrm{PM}_{10}$ aerosol Fe loading between 21 and 26 June (highlighted in Fig. 7). The inverse hyperbolic relationship presented by Sholkovitz et al. (2012) is different to that presented here - i.e. the lower fractional Fe solubility in the second cluster is associated with proximal fires (Fig. 7). Aged versus fresh combustion Fe can illuminate this discrepancy, and we discuss this in Sect. 4.6.4.

\subsection{Enrichment factor analysis}

Crustal enrichment factors (EFs) were calculated using the Wedepohl (1995) compilation of the continent crust to determine the contribution of mineral dust to the observed total elemental concentrations. Total Ti was used as a marker for mineral dust. For an element $(Z)$ in a sample, the EF relative to Ti is calculated using Eq. (2):

$\mathrm{EF}=\frac{(Z / \mathrm{Ti})_{\text {sample }}}{(Z / \mathrm{Ti})_{\text {crust }}}$.

The EFs of Gunn Point filters are used to aid our interpretation of mineral dust versus other aerosol sources. We recognise limitations of using EFs for this purpose, such as whether the reference material (Ti) is representative of mineral dust in the atmosphere compared to the crust (Reimann and Caritat, 2000; Arimoto et al., 1989). The majority of EFs in Table 2 are low, i.e. $\mathrm{EF}<5$. Enrichment factors in this range are similar to the upper continental crust, suggesting that these trace metals might have originated from that source (Duce et al., 1983; Gelado-Caballero et al., 2012). Aerosol Fe has an EF between 0.9 and 1.3 and does not show Fe enrichment. The low EFs imply that biomass burning is a relatively unimportant source of $\mathrm{Fe}$ in this study. However, the low values can be explained by processes, such as entrainment of fine soil particles into flames and smoke plumes, that could add $\mathrm{Fe}$ to the aerosol. This indirect contribution of $\mathrm{Fe}$ aerosol could be significant.

\subsection{Aerosol sources}

Based on a combination of radon, air mass trajectories, enrichment factor analysis, and biomass burning markers, trace 
Table 2. Enrichment factor analysis of Gunn Point aerosol samples.

\begin{tabular}{lrrrrrrr}
\hline & $\mathrm{Pb}$ & $\mathrm{Al}$ & $\mathrm{V}$ & $\mathrm{Cr}$ & $\mathrm{Mn}$ & $\mathrm{Fe}$ & $\mathrm{K}$ \\
\hline GP1 & 2.57 & 0.60 & 1.81 & 1.22 & 0.53 & 1.12 & 1.72 \\
GP2 & 3.18 & 0.76 & 2.24 & 1.54 & 0.67 & 1.28 & 1.91 \\
GP3 & 2.32 & 0.68 & 2.09 & 1.41 & 0.88 & 1.13 & 1.23 \\
GP4 & 1.38 & 0.64 & 1.93 & 1.26 & 0.88 & 1.07 & 0.67 \\
GP5 & 1.83 & 0.55 & 1.77 & 1.28 & 0.68 & 0.97 & 0.64 \\
GP6 & 3.42 & 0.59 & 1.72 & 1.34 & 1.03 & 1.03 & 2.17 \\
GP7 & 8.81 & 0.59 & 1.81 & 1.88 & 1.44 & 1.02 & 5.50 \\
GP8 & 3.77 & 0.66 & 2.08 & 1.34 & 0.72 & 1.15 & 1.49 \\
GP9 & 4.25 & 0.58 & 1.85 & 1.38 & 0.60 & 1.08 & 1.63 \\
GP10 & 3.42 & 0.67 & 2.29 & 7.93 & 0.49 & 1.16 & 1.37 \\
GP11 & 1.22 & 0.73 & 2.00 & 1.32 & 0.44 & 1.14 & 0.34 \\
GP12 & 2.05 & 0.64 & 1.95 & 1.48 & 1.47 & 1.14 & 1.23 \\
GP13 & 5.32 & 0.62 & 1.57 & 1.09 & 1.22 & 1.07 & 1.07 \\
GP14 & 6.55 & 0.64 & 1.67 & 1.16 & 1.48 & 1.08 & 2.30 \\
GP15 & 6.60 & 0.65 & 2.84 & 3.37 & 1.07 & 0.99 & 1.79 \\
GP16 & 2.39 & 0.62 & 1.77 & 0.99 & 1.40 & 0.88 & 1.49 \\
GP17 & 0.79 & 0.72 & 1.73 & 4.22 & 0.23 & 0.91 & 0.25 \\
GP18 & 1.63 & 0.67 & 2.09 & 1.34 & 0.52 & 1.04 & 0.48 \\
GP19 & 12.46 & 0.63 & 1.78 & 1.55 & 1.22 & 1.00 & 2.65 \\
GP20 & 8.05 & 0.68 & 1.60 & 1.25 & 4.70 & 1.10 & 4.79 \\
GP21 & 4.65 & 0.69 & 1.90 & 1.32 & 1.43 & 1.16 & 2.63 \\
GP22 & 5.72 & 0.71 & 1.96 & 1.37 & 2.18 & 1.12 & 3.92 \\
GP23 & 4.25 & 0.69 & 1.92 & 1.22 & 1.77 & 1.04 & 1.76 \\
\hline & & & & & & &
\end{tabular}

elements have been grouped into three sources: dust, biomass burning, and coastal sources.

\subsubsection{Dust events}

Dust events "A" and "B" are characterised by peaks in total $\mathrm{PM}_{10} \mathrm{Al}, \mathrm{Ti}, \mathrm{Fe}$, and $\mathrm{V}$, and correspond to low diurnal radon, i.e. when conditions are well mixed (Fig. 3). During these two dust events, air mass back trajectories corresponded to times when the air mass passed over central Australian desert, i.e. dust event "A", trajectory type "c", and dust event "B", trajectory type "d" (Fig. 1). Enrichment factors of $\mathrm{Al}$ (EF of 0.6-0.7), V (EF of 1.8-2.0) and Fe (EF of 1.0-1.1) during these two dust events suggest that these trace metals have a similar composition to the upper crust, i.e. $\mathrm{EF}<5$, and thus most likely originate from crustal material. Soluble concentrations of $\mathrm{Fe}, \mathrm{Al}, \mathrm{Ti}, \mathrm{Mn}$, and $\mathrm{V}$ were high during dust events "A" and "B". Fractional Fe solubility was highest in dust event "A" $(12 \%)$. Factors that influence fractional Fe solubility in mixed biomass burning and mineral dust sources are discussed in Sect. 4.6.

\subsubsection{Coastal conditions}

On 20 June 2014 coastal conditions were identified by a decrease in aerosol particle counts and a change in the particle size distribution from unimodal to bimodal with modes at 20 and $70 \mathrm{~nm}$ (Mallet et al., 2016). During these conditions, total $\mathrm{Na}$ reached $3.1 \mathrm{\mu g} \mathrm{m}^{-3}$ and the $\mathrm{Na} / \mathrm{Mg}$ ratio was similar to seawater, which is indicative of sea spray (Fig. 3). The $\mathrm{Na}$ signal was greater during times of low advective radon, i.e. when air masses were predominantly spending less time over land and more time over ocean regions. Total $\mathrm{PM}_{10} \mathrm{Al}, \mathrm{Ti}$, $\mathrm{Fe}$, and $\mathrm{V}$ peaked during these conditions. There was a moderate rise in soluble $\mathrm{Al}, \mathrm{Ti}$, and $\mathrm{Fe}$ concentrations. Enrichment factors for $\mathrm{Al}, \mathrm{V}$, and $\mathrm{Fe}$ during coastal conditions suggest that these trace metals have a similar composition to the upper crust (i.e. EF $0.7<5$ ) and might originate from crustal material. Fractional Fe solubility was $\sim 6 \%$ in the coastal air mass. During these conditions, there were also high concentrations of total $\mathrm{PM}_{10} \mathrm{Mo}, \mathrm{Cr}$, and As (Fig. 4). Small emissions of these three trace elements come from natural and anthropogenic sources (Lane et al., 2013; Pacyna and Nriagu, 1988). Back trajectories passed over coastal regions of moderate urban activity, i.e. trajectory type "b" (Fig. 1), suggesting that air masses could have contained a mixture of dust and minor anthropogenic-derived aerosols.

\subsubsection{Fire events}

The discussion of aerosol Fe during fire events focusses on the three major events occurring on 9 June (fire event "E"), 25 June (fire event "FG"), and 26-27 June 2014 (fire event "HI") (Desservettaz et al., 2016). These events were identified from large enhancements in $\mathrm{CO}$ concentrations and aerosol mass concentrations over the usual levels for the campaign (Desservettaz et al., 2016). Concentrations of nonrefractory particulate matter less than $1 \mu \mathrm{m}\left(\mathrm{PM}_{1}\right)$ increased up to $500 \mu \mathrm{g} \mathrm{m}^{-3}$ (Mallet et al., 2016). During fire events "FG" and "HI", total $\mathrm{PM}_{10} \mathrm{Fe}\left(400-800 \mathrm{ng} \mathrm{m}^{-3}\right)$ and soluble Fe (7-66 $\left.\mathrm{ng} \mathrm{m}^{-3}\right)$ concentrations and fractional Fe solubility $(\sim 3 \%$ ) were considerably less than the mean concentration and fractional solubility throughout the campaign. For the first half of the campaign, from 4 to 20 June, fractional Fe solubility averaged $10 \%$ and then dropped to $\sim 3 \%$ between 21 and 27 June. During the drop in fractional Fe solubility, soluble and total $\mathrm{PM}_{10} \mathrm{Fe}$ concentrations were the lowest found throughout the campaign.

We compare the fractional Fe solubility to biomass burning proxies during the campaign. There is no significant relationship between fractional Fe solubility and the biomass burning tracers (nss-K, elemental carbon, oxalate, or levoglucosan) throughout campaign (Fig. S2 in the Supplement). Nevertheless, fractional Fe solubility is typically lower when elemental carbon concentrations are high, excluding dust event "A" $\left(r^{2}=0.33\right)$. The period of low fractional Fe solubility $\sim 3 \%$, between 21 and 27 June, encompasses the exceptionally large fire events "FG" and "HI". Biomass burning was most intense during this second half of the campaign. In agreement with high concentrations of elemental carbon, oxalate, and levoglucosan at this time, visual examination of the aerosol filters showed that filters were exceptionally caked with soot between 21 and 27 June. The lowest fractional $\mathrm{Fe}$ solubility during fire event "FG" and "HI" is related to prox- 
imal fires, whilst the fractional Fe solubility was relatively high during fire event "E", when fires were distantly sourced.

\subsection{Biomass-burning-derived soluble iron - combustion and transport}

During the large burning events in this study, fresh elemental carbon is an insignificant source of soluble Fe to the aerosol; fresh elemental carbon has a relatively low Fe solubility (Ito, 2015), is initially hydrophobic (e.g. Chughtai et al., 1996), and contains relatively little Fe (e.g. Maenhaut et al., 2002). However, biomass burning can indirectly influence the fractional $\mathrm{Fe}$ solubility of aerosols through physical processes, such as the entrainment of local soil particles into the smoke plume, black-carbon-containing particles acting as a substrate for long-range aerosol Fe transport, and the fine particle size of biomass-burning-derived particles. In addition, chemical processes, such as oxalate modification and aerosol aging, may also impact fractional Fe solubility in biomass burning plumes. The low fractional Fe solubility of $\sim 3 \%$ during periods of high elemental carbon, oxalate, and levoglucosan concentrations could be related to the entrainment of fine soil particles into the smoke plume during intensive fires. The incorporation of local dust into the aerosol explains the low EFs and elevated nss- $\mathrm{K} / \mathrm{Fe}$ ratios during the largest fire events. Back trajectories and radon also show that mineral dust was sourced from central Australian desert. The fractional Fe solubility at this time is similar to dust estimates around $0.5-2 \%$ at relatively high $\mathrm{Fe}$ mass concentrations (Sholkovitz et al., 2012).

\subsubsection{Aggregation of particles during atmospheric transport}

Iron can be bound to long-range-transportable black-carboncontaining particle aggregates deposited in Antarctic snow and ice (Ellis et al., 2015). Little is known about the process in which $\mathrm{Fe}$ is bound to black-carbon-containing particle aggregates. Iron could originate from Fe contained within the biomass (Maenhaut et al., 2002; Yamasoe et al., 2000; Reid et al., 2005), local soil Fe incorporated into the aerosol mixture during combustion, or the binding of aerosol Fe to black-carbon-containing particles in the atmosphere during transport. Using single particle analysis, mixed sources (e.g. black carbon and aluminosilicates) were detected in aerosols transported over long range to Antarctica (Ellis et al., 2015). The fractional $\mathrm{Fe}$ solubility data $(2-12 \%)$ plot in the middle range for aerosol Fe sources characteristic of dust and combustion in the Southern Hemisphere (Fig. 7).

\subsubsection{Particle size distribution of biomass-burning-derived particles}

The particle size distribution of biomass burning aerosols was typically centred around $95 \mathrm{~nm}$ (with $95 \%$ of all particles between 30 and $280 \mathrm{~nm}$ ) for nearby fresh smoke at Gunn
Point and around $120 \mathrm{~nm}$ (95\% of all particles were between 40 and $390 \mathrm{~nm}$ ) for distant aged smoke at Gunn Point (Mallet et al., 2016). However, for aged/long-range-transported smoke, the literature shows that the particle size distribution ranges between 75 and $540 \mathrm{~nm}$ (Kipling et al., 2013). As the particle size distribution for black carbon is in the nanometre range, any $\mathrm{Fe}$ associated with black-carbon-containing particles is operationally defined as soluble (i.e. $<0.2 \mu \mathrm{m}$ ). The majority of soluble $\mathrm{Fe}$ in Gunn Point aerosols during large biomass burning events was within this $<0.2 \mu \mathrm{m}$ pool (i.e. the concentration of soluble $\mathrm{Fe}<0.2 \mu \mathrm{m}$ was $7 \mathrm{ng} \mathrm{m}^{-3}$ compared to the bulk soluble Fe concentration of $10 \mathrm{ng} \mathrm{m}^{-3}$ in sample GP22). $\mathrm{PM}_{1}$ ambient aerosols sampled during the SAFIRED campaign were dominated by an organic fraction (Milic et al., 2016). Many of the finer particles are also likely to be derived from biomass burning, given that the particle size distribution of biomass burning aerosols at Gunn Point was typically centred around $100 \mathrm{~nm}$ (Mallet et al., 2016) and thus operationally defined as soluble. Recent studies show that nanometre-sized $\mathrm{Fe}$ particles are potentially bioavailable (e.g. Raiswell et al., 2008). The proportion of soluble Fe in the $<0.2 \mu \mathrm{m}$ pool is likely to vary between the dry and wet season as different aerosol sources switch on and off - i.e. mineral dust has a coarser particle size distribution than biomass-burning-derived particles. Future work should be directed towards quantifying biomass burning sources of bioavailable $\mathrm{Fe}$ in tropical and remote oceanic regions.

\subsubsection{Oxalate modification}

Oxalate modification of mineral dust could be a leading factor enhancing the fractional $\mathrm{Fe}$ solubility of mineral dust (Ito and Shi, 2016) in regions where there are high oxalate concentrations in the atmosphere, such as the tropics. The higher fractional Fe solubility during dust events at Gunn Point could be related to biomass-burning-derived oxalate enhancing the solubility of Australian mineral dust that has been transported to the Northern Territory and mixed with biomass burning plumes (Fig. 6). The fractional Fe solubility of mineral dust in the Southern Hemisphere is around 0.5$2 \%$ (Sholkovitz et al., 2012), which is lower than our estimates of fractional Fe solubility during dust events in northern Australia during the dry season. Only trace concentrations of oxalate are found in air masses in lower latitudes over Antarctica and the Southern Ocean (Keywood, 2007). However, little is known about the enhancement of fractional Fe solubility in these pristine air masses (Chance et al., 2015; Winton et al., 2015a), and the concentrations of oxalate could be too low to influence fractional Fe solubility of mineral dust. Therefore, the mean mineral dust fractional Fe solubility of $\sim 8 \%$ represents an upper bound of mineral dust fractional Fe solubility in the Australian tropics during the dry season as illustrated in Fig. 7. 


\subsubsection{Aging of biomass-burning-derived particles}

Despite the influx of aerosols from proximal fires, the fractional $\mathrm{Fe}$ solubility remained low between 21 and 27 June (Fig. 6). This relationship could be related to the hydrophobic, i.e. water-insoluble, nature of black-carbon-containing particles (e.g. Chughtai et al., 1996). The low soluble Fe concentrations, and low fractional Fe solubility, derived from the heavily caked soot filters between 21 and 27 June could reflect the physical properties of fresh black carbon - i.e. fresh black carbon does not disperse in water and thus any soluble Fe associated with fresh black carbon is not incorporated into the water leachate. However, combustion aerosols are known to have a high fractional Fe solubility (Sholkovitz et al., 2012) and often these studies are based on aerosols collected on shipboard in the remote open ocean where aerosol $\mathrm{Fe}$ has undergone atmospheric transport and aging. Therefore, the fractional $\mathrm{Fe}$ solubility in these studies is not directly comparable to fresh combustion $\mathrm{Fe}$ reported in this study. Combustion aerosols can become more soluble with transport (Ito, 2015). There is a growing body of work that suggests aerosol $\mathrm{Fe}$ solubility can be enhanced by cloud chemistry and acid processing (Meskhidze et al., 2003; Spokes et al., 1994; Desboeufs et al., 1999; Kumar et al., 2010). Ito and Shi (2016) show that enhanced Fe solubility of dust could be related to reactive organic species, such as oxalate, in cloud water, which contains Fe-binding functionalities such as humic-like substances from biomass burning. In a review of Fe chemistry in systems containing humic-like substances, Al-Abadleh (2015) highlights the complexation and dissolution processes in which aerosol Fe solubility is enhanced with organic compounds. Fresh black-carbon-containing particles are initially insoluble, but they can be aged into a form that disperses in water following uptake of sulfuric acid and secondary organic material via condensation and coagulation in the atmosphere. Black carbon particles can act as a seed for condensation, and the components that condense on the surface of the black carbon particles are water-soluble. Aged black-carbon-containing particles can also disperse in water through the oxidation of functional groups during atmospheric transport over the remote ocean (Lohmann et al., 2000; Decesari et al., 2002; Chughtai et al., 1991, 1996). If the surface of black carbon particles becomes hydrophilic with a coating of water-soluble species in the atmosphere, soluble Fe bound to the black-carbon-containing particles would disperse in water and be captured in the Fe leachate. There was no significant atmospheric processing of proximal fires during the SAFIRED campaign (Milic et al., 2016). The lack of atmospheric processing could explain why (i) the fractional $\mathrm{Fe}$ solubility was higher in distally sourced fire event "E" compared to proximal fire events "FG" and "HI" and (ii) relatively high fractional Fe solubility is observed in aerosol Fe transported over long-range distances to the remote Southern Ocean and Antarctica (Conway et al., 2015; Gaspari et al., 2006; Winton et al., 2015a, 2016b). The im- pact of transport time and distance on fractional Fe solubility should be further investigated.

We provide evidence that $\mathrm{Fe}$ in freshly emitted biomass burning aerosols is not particularly soluble. In turn, this suggests that atmospheric aging itself plays a significant role in observations of soluble $\mathrm{Fe}$ in smoke plumes sampled far from combustion sources. Ito (2015) model the transport of soluble Fe derived from combustion sources. The model indicates relatively low fractional $\mathrm{Fe}$ solubility near the sources of biomass burning and coal combustion. The fractional Fe solubility becomes higher as aerosols are transported to the open ocean. Therefore, transport time and distance could be an important factor in the variability of fractional Fe solubility estimates. Alternatively, the relatively low fractional Fe solubility could be related to the type of biomass in northern Australia, i.e. savannah that is comprised of eucalypt-dominated woodlands (10-30\% foliage cover) and open forests (30$70 \%$ foliage cover), with a diverse woody sub-canopy and grassy ground cover (Edwards et al., 2015). There is a wide range of fractional $\mathrm{Fe}$ solubility estimates for combustion aerosols in the literature and more studies are required to understand the fractional $\mathrm{Fe}$ solubility in different biomass types. On the other hand, the low fractional $\mathrm{Fe}$ solubility during fire events raises questions whether biomass burning could be a potential bioavailable source of $\mathrm{Fe}$ to the ocean. In a study of biomass burning-related emissions of $\mathrm{Fe}$ in the Mediterranean, Guieu et al. (2005) found that fractional Fe solubility was lower than this study (0.6-2\%) and concluded that while biomass burning may have a significant local effect on aerosol Fe supply to the ocean, on a global scale biomass burning has little impact. Clearly future work should be directed towards the solubility of Fe in fresh and aged smoke plumes. We have focused our discussion around the fractional Fe solubility of mixed biomass burning aerosols and mineral dust. The trends in fractional $\mathrm{Fe}$ solubility paralleled fractional $\mathrm{Al}$ and $\mathrm{Ti}$ (but not $\mathrm{Mn}$ ) solubility throughout the campaign, implying that the factors that regulate fractional Fe solubility in these samples may also regulate the solubility of $\mathrm{Al}$ and Ti. Little is known about the fractional $\mathrm{Al}$, $\mathrm{Ti}$, and $\mathrm{Mn}$ solubility in biomass-burning-derived aerosols. Again, future studies should investigate these $\mathrm{Fe}, \mathrm{Al}$, and $\mathrm{Ti}$ aerosols in conjunction both at the source and in long-rangetransported air masses downwind of biomass burning.

\section{Conclusions}

Co-emissions of mineral dust and aged biomass burning from Australia are potential sources of soluble $\mathrm{Fe}$ to Australian tropical waters. During the SAFIRED campaign, northern Australia in the dry season 2014, there was considerable temporal variability in soluble and total $\mathrm{PM}_{10}$ aerosol Fe concentrations that reflect coincident mineral dust and fresh smoke sources. Fractional Fe solubility was relatively high throughout the campaign and ranged from 2 to $12 \%$. During dust 
events, the fractional Fe solubility was greatest (12\%); however, it decreased to $3 \%$ during an intense biomass burning period. Whilst mineral dust supplied soluble Fe throughout the campaign, the lower fractional Fe solubility in the large biomass burning events suggests that the primary factor controlling soluble $\mathrm{Fe}$ was the presence of mineral dust. The dust could have been entrained into the biomass burning plume from local soil and also transported from central Australian deserts. Due to the hydrophobic nature of fresh black carbon and the low total Fe content, biomass burning itself may not be a direct source of soluble Fe to the ocean. Nevertheless, biomass burning species can enhance the soluble Fe chemistry in mixed aerosols. Iron in dust may be more soluble in the tropics compared to higher latitudes, due to the higher concentrations of biomass-burning-derived reactive organic species in the atmosphere, such as oxalate, and their potential to enhance the fractional Fe solubility of mineral dust during transport. Soluble Fe could be further enhanced during atmospheric transport and aging of blackcarbon-containing particles that could explain the relatively high episodic fractional Fe solubility observed in long-rangetransportable aerosol Fe to the Southern Ocean and Antarctica. In addition, black-carbon-containing particles can act as a surface for aerosol $\mathrm{Fe}$ to bind to during transport. Biomass burning constitutes a large fraction of the aerosol loading over the tropics which has the potential to modulate soluble $\mathrm{Fe}$ and trigger nitrogen-fixing toxic algal blooms. Such toxic algal blooms have harmful consequences for humans and other vertebrates. The understanding of the factors that initiate algal blooms needs to be improved (Law et al., 2011; Abram et al., 2003), especially over tropical regions where inputs of biomass burning to the ocean are predicted to increase over the next century (Keywood et al., 2013).

\section{Data availability}

The trace element data set is available through the Curtin University Research Data repository (http://doi.org/10.4225/ 06/5671012A48C2A).

\section{The Supplement related to this article is available online at doi:10.5194/acp-16-12829-2016-supplement.}

Author contributions. V. H. L. Winton, R. Edwards, and A. R. Bowie designed the research; V. H. L. Winton and M. Desservettaz collected the aerosol filters; V. H. L. Winton, R. Edwards, and A. R. Bowie prepared the trace element filter samples, analysed and evaluated the data; P. W. Selleck prepared the elemental carbon and major ion filter samples and analysed the data; M. Desservettaz and C. Paton-Walsh collected and analysed the carbon monoxide data; S. Chambers and A. G. Williams collected and analysed the radon data; M. Mallet and M. Keywood analysed the particle size distribution data; M. Keywood, P. W. Selleck, S. Chambers, A. G. Williams, M. Mallet, M. Desservettaz, C. Paton-Walsh, and V. H. L. Winton contributed to the field campaign; and V. H. L. Winton prepared the manuscript with contributions from all co-authors.

Acknowledgements. This paper is a contribution to the Savannah Fires in the Early Dry Season (SAFIRED) campaign. This project was funded through Curtin University (RES-SE-DAP-AW-476791 to R. Edwards), the University of Tasmania (B0019024 to A. R. Bowie), the Australian Research Council (FT130100037 to A. R. Bowie), the Antarctic Climate and Ecosystems Cooperative Research Centre (ARC CRC), and CSIRO. Access to HR-ICP-MS instrumentation at Curtin University was facilitated through ARC LIEF funding (LE130100029). V. H. L. Winton would like to acknowledge the following scholarship support: an Australian Postgraduate Award, a Curtin Research Scholarship, a CUPSA data collection grant, and a Curtin University Publication Scholarship. Thank you to CSIRO Ocean and Atmosphere for the use of their high-volume aerosol sampler and to the Bureau of Meteorology for the use of their site throughout the campaign. Thank you to the SAFIRED team, in particular to Rob Gillet and Jason Ward for assisting with the change-over of daily aerosol filters and to Brad Atkinson from the Bureau of Meteorology for assistance at Gunn Point. Thank you to Sylvester Werczynski for installing and maintaining the ANSTO radon detector, and for obtaining the back trajectories from HYSPLIT and cataloguing them in a database for use with the Gunn Point data. Thank you to Pier van der Merwe for technical support with aerosol digestions. Wind roses were created using the OpenAir package in $\mathrm{R}$ and meteorological data from the Bureau of Meteorology. We thank the three anonymous reviewers for their constructive comments which improved this manuscript.

Edited by: S. A. Nizkorodov

Reviewed by: three anonymous referees

\section{References}

Abram, N. J., Gagan, M. K., McCulloch, M. T., Chappell, J., and Hantoro, W. S.: Coral reef death during the 1997 Indian Ocean dipole linked to Indonesian wildfires, Science, 301, 952-955, 2003.

Aguilar-Islas, A. M., Wu, J., Rember, R., Johansen, A. M., and Shank, L. M.: Dissolution of aerosol-derived iron in seawater: Leach solution chemistry, aerosol type, and colloidal iron fraction, Mar. Chem., 120, 25-33, 2010.

Al-Abadleh, H. A.: Review of the bulk and surface chemistry of iron in atmospherically relevant systems containing humic-like substances, RSC Adv., 5, 45785-45811, 2015.

Andersen, A. N., Cook, G. D., Corbett, L. K., Douglas, M. M., Eager, R. W., Russell-Smith, J., Setterfield, S. A., Williams, R. J., and Woinarski, J. C.: Fire frequency and biodiversity conservation in Australian tropical savannas: implications from the Kapalga fire experiment, Austral. Ecol., 30, 155-167, 2005.

Andreae, M. O. and Gelencsér, A.: Black carbon or brown carbon? The nature of light-absorbing carbonaceous aerosols, At- 
mos. Chem. Phys., 6, 3131-3148, doi:10.5194/acp-6-3131-2006, 2006.

Arimoto, R., Duce, R. A., and Ray, B. J.: Concentrations, sources and air-sea exchange of trace elements in the atmosphere over the Pacific Ocean, Chem. Oceanogr., 10, 107-149, 1989.

Baker, A., Kelly, S., Biswas, K., Witt, M., and Jickells, T.: Atmospheric deposition of nutrients to the Atlantic Ocean, Geophys. Res. Lett., 30, doi:10.1029/2003GL018518, 2003.

Baker, A., Weston, K., Kelly, S., Voss, M., Streu, P., and Cape, J.: Dry and wet deposition of nutrients from the tropical Atlantic atmosphere: Links to primary productivity and nitrogen fixation, Deep Sea Res., 54, 1704-1720, 2007.

Baker, A., Adams, C., Bell, T., Jickells, T., and Ganzeveld, L.: Estimation of atmospheric nutrient inputs to the Atlantic Ocean from $50^{\circ} \mathrm{N}$ to $50^{\circ} \mathrm{S}$ based on large-scale field sampling: Iron and other dust-associated elements, Global Biogeochem. Cy., 27, 755-767, 2013.

Baker, A. R. and Croot, P. L.: Atmospheric and marine controls on aerosol iron solubility in seawater, Mar. Chem., 120, 4-13, 2010.

Baker, A. R., Jickells, T. D., Witt, M., and Linge, K. L.: Trends in the solubility of iron, aluminium, manganese and phosphorus in aerosol collected over the Atlantic Ocean, Mar. Chem., 98, 4358, 2006.

Berman-Frank, I., Cullen, J. T., Shaked, Y., Sherrell, R. M., and Falkowski, P. G.: Iron availability, cellular iron quotas, and nitrogen fixation in Trichodesmium, Limnol. Oceanogr., 46, 1249 1260, 2001.

Bisiaux, M. M., Edwards, R., McConnell, J. R., Curran, M. A. J., Van Ommen, T. D., Smith, A. M., Neumann, T. A., Pasteris, D. R., Penner, J. E., and Taylor, K.: Changes in black carbon deposition to Antarctica from two high-resolution ice core records, 1850-2000 AD, Atmos. Chem. Phys., 12, 4107-4115, doi:10.5194/acp-12-4107-2012, 2012.

Bond, T. C., Doherty, S. J., Fahey, D. W., Forster, P. M., Berntsen, T., DeAngelo, B. J., Flanner, M. G., Ghan, S., Kärcher, B., Koch, D., Kinne, S., Kondo, Y., Quinn, P. K., Sarofim, M. C., Schultz, M. G., Schulz, M., Venkataraman, C., Zhang, H., Zhang, S., Bellouin, N., Guttikunda, S. K., Hopke, P. K., Jacobson, M. Z., Kaiser, J. W., Klimont, Z., Lohmann, U., Schwarz, J. P., Shindell, D., Storelvmo, T., Warren, S. G., and Zender, C. S.: Bounding the role of black carbon in the climate system: A scientific assessment, J. Geophys. Res.-Atmos., 118, 5380-5552, doi:10.1002/jgrd.50171, 2013.

Bowie, A. R., Lannuzel, D., Remenyi, T. A., Wagener, T., Lam, P. J., Boyd, P. W., Guieu, C., Townsend, A. T., and Trull, T. W.: Biogeochemical iron budgets of the Southern Ocean south of Australia: Decoupling of iron and nutrient cycles in the subantarctic zone by the summertime supply, Global Biogeochem. Cy., 23, GB4034, doi:10.1029/2009GB003500, 2009.

Bowler, J.: Aridity in Australia: age, origins and expression in aeolian landforms and sediments, Earth-Sci. Rev., 12, 279-310, 1976.

Boyd, P. W. and Ellwood, M. J.: The biogeochemical cycle of iron in the ocean, Nature Geosci, 3, 675-682, 2010.

Boyd, P. W., Watson, A. J., Law, C. S., Abraham, E. R., Trull, T., Murdoch, R., Bakker, D. C. E., Bowie, A. R., Buesseler, K. O., Chang, H., Charette, M., Croot, P. L., Downing, K., Frew, R., Gall, M., Hadfield, M., Hall, J., Harvey, M., Jameson, G., LaRoche, J., Liddicoat, M. I., Ling, R., Maldonado, M. T.,
McKay, R. M., Nodder, S., Pickmere, S., Pridmore, R., Rintoul, S., Safi, K., Sutton, P., Strzepek, R., Tanneberger, K., Turner, S., Waite, A., and Zeldis, J.: A mesoscale phytoplankton bloom in the polar Southern Ocean stimulated by iron fertilization, Nature, 407, 695-702, 2000.

Boyd, P. W., Mackie, D. S., and Hunter, K. A.: Aerosol iron deposition to the surface ocean - Modes of iron supply and biological responses, Mar. Chem., 120, 128-143, 2010.

Carslaw, D. C.: The openair manual - open-source tools for analysing air pollution data, manual for version 1.0, King's College London, 2014.

Carslaw, D. C. and Ropkins, K.: Openair - An R package for air quality data analysis, Environ. Model. Softw., 27, 52-61, 2012.

Chambers, S. D., Hong, S.-B., Williams, A. G., Crawford, J., Griffiths, A. D., and Park, S.-J.: Characterising terrestrial influences on Antarctic air masses using Radon-222 measurements at King George Island, Atmos. Chem. Phys., 14, 9903-9916, doi:10.5194/acp-14-9903-2014, 2014.

Chambers, S. D., Williams, A. G., Crawford, J., and Griffiths, A. D.: On the use of radon for quantifying the effects of atmospheric stability on urban emissions, Atmos. Chem. Phys., 15, 1175-1190, doi:10.5194/acp-15-1175-2015, 2015.

Chance, R., Jickells, T. D., and Baker, A. R.: Atmospheric trace metal concentrations, solubility and deposition fluxes in remote marine air over the south-east Atlantic, Mar. Chem., 177, 45-56, doi:10.1016/j.marchem.2015.06.028, 2015.

Chow, J. C., Watson, J. G., Chen, L.-W. A., Chang, M. O., Robinson, N. F., Trimble, D., and Kohl, S.: The IMPROVE_A temperature protocol for thermal/optical carbon analysis: maintaining consistency with a long-term database, J. Air Waste Manage. Assoc., 57, 1014-1023, 2007.

Chuang, P. Y., Duvall, R. M., Shafer, M. M., and Schauer, J. J.: The origin of water soluble particulate iron in the Asian atmospheric outflow, Geophys. Res. Lett., 32, L07813, doi:10.1029/2004GL021946, 2005.

Chughtai, A., Jassim, J., Peterson, J., Stedman, D., and Smith, D.: Spectroscopic and solubility characteristics of oxidized soots, Aerosol Sci. Technol., 15, 112-126, 1991.

Chughtai, A., Brooks, M., and Smith, D.: Hydration of black carbon, J. Geophys. Res.-Atmos., 101, 19505-19514, 1996.

Conway, T., Wolff, E., Röthlisberger, R., Mulvaney, R., and Elderfield, H.: Constraints on soluble aerosol iron flux to the Southern Ocean at the Last Glacial Maximum, Nature Comm., 6, 1-9, 2015.

Cropp, R. A., Gabric, A. J., Levasseur, M., McTainsh, G. H., Bowie, A., Hassler, C. S., Law, C. S., McGowan, H., Tindale, N., and Viscarra Rossel, R.: The likelihood of observing dust-stimulated phytoplankton growth in waters proximal to the Australian continent, J. Mar. Syst., 117-118, 43-52, doi:10.1016/j.jmarsys.2013.02.013, 2013.

Cutter, G., Andersson, P., Codispoti, L., Croot, P., Francois, R., Lohan, M., Obata, H., and Rutgers vd Loeff, M.: Sampling and sample-handling protocols for GEOTRACES Cruises, http://www.jodc.go.jp/geotraces/docs/GEOTRACES_ IPYProtocols-Final.pdf, 2010.

Decesari, S., Facchini, M., Matta, E., Mircea, M., Fuzzi, S., Chughtai, A., and Smith, D.: Water soluble organic compounds formed by oxidation of soot, Atmos. Environ., 36, 1827-1832, 2002. 
De Deckker, P., Norman, M., Goodwin, I. D., Wain, A., and Gingele, F. X.: Lead isotopic evidence for an Australian source of aeolian dust to Antarctica at times over the last 170,000 years, Palaeogeogr. Palaeoclimatol. Palaeoecol., 285, 205-223, 2010.

Desboeufs, K., Losno, R., Vimeux, F., and Cholbi, S.: The pHdependent dissolution of wind-transported Saharan dust, J. Geophys. Res.-Atmos., 104, 21287-21299, 1999.

Desservettaz, M., Paton-Walsh, C., Griffith, D. W. T., Kettlewell, G., Keywood, M. D., Vanderschoot, M. V., Ward, J., Mallet, M. D., Milic, A., Miljevic, B., Ristovski, Z. D., Howard, D., Edwards, G. C., and Atkinson, B.: Emission factors of trace gases and particles from tropical savanna fires in Australia, in review, J. Geophys. Res.-Atmos., 2016.

Dörr, H., Kromer, B., Levin, I., Münnich, K., and Volpp, H. J.: $\mathrm{CO}_{2}$ and Radon 222 as tracers for atmospheric transport, J. Geophys. Res.-Ocean., 88, 1309-1313, 1983.

Draxler, R. R. and Rolph, G. D.: Hybrid Single-Particle Lagrangian Integrated Trajectory (HYSPLIT), model, available at: http://www.arl.noaa.gov/ready/hysplit4.html (last access: 30 July 2014), 2003.

Duce, R., Arimoto, R., Ray, B., Unni, C., and Harder, P.: Atmospheric trace elements at Enewetak Atoll: 1. Concentrations, sources, and temporal variability, J. Geophys. Res.-Ocean., 88, 5321-5342, 1983.

Duce, R. A., Liss, P. S., Merrill, J. T., Atlas, E. L., Buat-Menard, P., Hicks, B. B., Miller, J. M., Prospero, J. M., Arimoto, R., Church, T. M., Ellis, W., Galloway, J. N., Hansen, L., Jickells, T. D., Knap, A. H., Reinhardt, K. H., Schneider, B., Soudine, A., Tokos, J. J., Tsunogai, S., Wollast, R., and Zhou, M.: The atmospheric input of trace species to the world ocean, Global Biogeochem. Cy., 5, 193-259, doi:10.1029/91GB01778, 1991.

Edwards, A., Russell-Smith, J., and Meyer, M.: Contemporary fire regime risks to key ecological assets and processes in north Australian savannas, Int. J. Wildl. Fire, 24, 857-870, 2015.

Ellis, A., Edwards, R., Saunders, M., Chakrabarty, R. K., Subramanian, R., van Riessen, A., Smith, A. M., Lambrinidis, D., Nunes, L. J., Vallelonga, P., Goodwin, I. D., Moy, A. D., Curran, M. A. J., and van Ommen, T. D.: Characterizing black carbon in rain and ice cores using coupled tangential flow filtration and transmission electron microscopy, Atmos. Meas. Tech., 8, 3959-3969, doi:10.5194/amt-8-3959-2015, 2015.

Elrod, V., Berelson, W., Coale, K., and Johnson, K.: The flux of iron from continental shelf sediments: a missing source for global budgets, Geophys Res Lett, 31, L12307, doi:10.1029/2004GL020216, 2004.

Falkowski, P. G.: Evolution of the nitrogen cycle and its influence on the biological sequestration of $\mathrm{CO}_{2}$ in the ocean, Nature, 387, 272-275, 1997.

Fishwick, M. P., Sedwick, P. N., Lohan, M. C., Worsfold, P. J., Buck, K. N., Church, T. M., and Ussher, S. J.: The impact of changing surface ocean conditions on the dissolution of aerosol iron, Global Biogeochem. Cy., 28, 1235-1250, doi:10.1002/2014GB004921, 2014.

Gabric, A. J., Cropp, R. A., McTainsh, G. H., Johnston, B. M., Butler, H., Tilbrook, B., and Keywood, M.: Australian dust storms in 2002-2003 and their impact on Southern Ocean biogeochemistry, Global Biogeochem. Cy., 24, doi:10.1029/2009GB003541, 2010.
Gao, Y., Xu, G., Zhan, J., Zhang, J., Li, W., Lin, Q., Chen, L., and Lin, H.: Spatial and particle size distributions of atmospheric dissolvable iron in aerosols and its input to the Southern Ocean and coastal East Antarctica, J. Geophys. Res.-Atmos., 118, 1263412648, 2013.

Garcia, N. S., Fu, F., Sedwick, P. N., and Hutchins, D. A.: Iron deficiency increases growth and nitrogen-fixation rates of phosphorus-deficient marine cyanobacteria, ISME J., 9, 238245, doi:10.1038/ismej.2014.104, 2015.

Gaspari, V., Barbante, C., Cozzi, G., Cescon, P., Boutron, C. F., Gabrielli, P., Capodaglio, G., Ferrari, C., Petit, J. R., and Delmonte, B.: Atmospheric iron fluxes over the last deglaciation: Climatic implications, Geophys. Res. Lett., 33, L03704, doi:10.1029/2005GL024352, 2006.

Gelado-Caballero, M. D., López-García, P., Prieto, S., Patey, M. D., Collado, C., and Hérnández-Brito, J. J.: Long-term aerosol measurements in Gran Canaria, Canary Islands: Particle concentration, sources and elemental composition, J. Geophys. Res.Atmos., 117, doi:10.1029/2011JD016646, 2012.

Giglio, L., Randerson, J. T., and Werf, G. R.: Analysis of daily, monthly, and annual burned area using the fourth-generation global fire emissions database (GFED4), J. Geophys. Res.Biogeosci., 118, 317-328, 2013.

Guieu, C., Bonnet, S., Wagener, T., and Loÿe-Pilot, M. D.: Biomass burning as a source of dissolved iron to the open ocean?, Geophys. Res. Lett., 32, doi:10.1029/2005GL022962, 2005.

Hesse, P. P.: The record of continental dust from Australia in Tasman Sea sediments, Quat. Sci. Rev., 13, 257-272, 1994.

Hesse, P. P. and McTainsh, G. H.: Australian dust deposits: modern processes and the Quaternary record, Quat. Sci. Rev., 22, 20072035, 2003.

Hibberd, M., Selleck, P., Keywood, M., Cohen, D., Stelcer, E., and Atanacio, A.: Upper Hunter Particle Characterisation Study, Australia: CSIRO, http://141.243.32.146/resources/aqms/ UHFPCSFinal.pdf, 1-72, 2013.

Iinuma, Y., Engling, G., Puxbaum, H., and Herrmann, H.: A highly resolved anion-exchange chromatographic method for determination of saccharidic tracers for biomass combustion and primary bio-particles in atmospheric aerosol, Atmos. Environ., 43, 13671371, 2009.

Ito, A.: Mega fire emissions in Siberia: potential supply of bioavailable iron from forests to the ocean, Biogeosciences, 8, 16791697, doi:10.5194/bg-8-1679-2011, 2011.

Ito, A.: Global modeling study of potentially bioavailable iron input from shipboard aerosol sources to the ocean, Global Biogeochem. Cy., 27, 1-10, 2013.

Ito, A.: Atmospheric Processing of Combustion Aerosols as a Source of Bioavailable Iron, Environ. Sci. Technol. Lett., 2, 7075, doi:10.1021/acs.estlett.5b00007, 2015.

Ito, A. and Shi, Z.: Delivery of anthropogenic bioavailable iron from mineral dust and combustion aerosols to the ocean, Atmos. Chem. Phys., 16, 85-99, doi:10.5194/acp-16-85-2016, 2016.

Johnson, K. S., Gordon, R. M., and Coale, K. H.: What controls dissolved iron concentrations in the world ocean?, Mar. Chem., 57, 137-161, 1997.

Johnston, S. W.: The influence of aeolian dust deposits on alpine soils in south-eastern Australia, Soil Res., 39, 81-88, 2001.

Keene, W. C., Pszenny, A. A., Galloway, J. N., and Hawley, M. E.: Sea-salt corrections and interpretation of constituent ratios in 
marine precipitation, J. Geophys. Res.-Atmos., 91, 6647-6658, 1986.

Keywood, M., Kanakidou, M., Stohl, A., Dentener, F., Grassi, G., Meyer, C., Torseth, K., Edwards, D., Thompson, A. M., and Lohmann, U.: Fire in the air: biomass burning impacts in a changing climate, Crit. Rev. Environ. Sci. Technol., 43, 40-83, 2013.

Keywood, M. D.: Aerosol composition at Cape Grim: an evaluation of $\mathrm{PM}_{10}$ sampling program and baseline event switches., Baseline Atmospheric Program Australia 2005-2006, edited by: Cainey, J. M., Derek, N., and Krummel, P. B., Melbourne, Australian Bureau of Meteorology and CSIRO Marine and Atmospheric Research, 31-36, 2007.

Kipling, Z., Stier, P., Schwarz, J. P., Perring, A. E., Spackman, J. R., Mann, G. W., Johnson, C. E., and Telford, P. J.: Constraints on aerosol processes in climate models from vertically-resolved aircraft observations of black carbon, Atmos. Chem. Phys., 13, 5969-5986, doi:10.5194/acp-13-5969-2013, 2013.

Knapp, A. N., Casciotti, K. L., Berelson, W. M., Prokopenko, M. G., and Capone, D. G.: Low rates of nitrogen fixation in eastern tropical South Pacific surface waters, P. Natl. Acad. Sci., 113, 4398-4403, doi:10.1073/pnas.1515641113, 2016.

Kumar, A., Sarin, M., and Srinivas, B.: Aerosol iron solubility over Bay of Bengal: Role of anthropogenic sources and chemical processing, Mar. Chem., 121, 167-175, 2010.

Kustka, A. B., Sañudo-Wilhelmy, S. A., Carpenter, E. J., Capone, D., Burns, J., and Sunda, W. G.: Iron requirements for dinitrogenand ammonium-supported growth in cultures of Trichodesmium (IMS 101): Comparison with nitrogen fixation rates and iron: Carbon ratios of field populations, Limnol. Oceanogr., 48, 18691884, 2003.

Lane, S., Proemse, B. C., Tennant, A., and Wieser, M. E.: Concentration measurements and isotopic composition of airborne molybdenum collected in an urban environment, Anal. Bioanal. Chem., 405, 2957-2963, 2013.

LaRoche, J. and Breitbarth, E.: Importance of the diazotrophs as a source of new nitrogen in the ocean, J. Sea Res., 53, 67-91, 2005.

Law, C., Woodward, E., Ellwood, M., Marriner, A., Bury, S., and Safi, K.: Response of surface nutrient inventories and nitrogen fixation to a tropical cyclone in the southwest Pacific, Limnol. Oceanogr., 56, 1372-1385, 2011.

Lenes, J., Darrow, B., Walsh, J., Prospero, J., He, R., Weisberg, R., Vargo, G., and Heil, C.: Saharan dust and phosphatic fidelity: A three-dimensional biogeochemical model of Trichodesmium as a nutrient source for red tides on the West Florida Shelf, Cont. Shelf Res., 28, 1091-1115, 2008.

Lohmann, U., Feichter, J., Penner, J., and Leaitch, R.: Indirect effect of sulfate and carbonaceous aerosols - A mechanistic treatment, J. Geophys.-Res., 105, 12193-12206, 2000.

Mackie, D. S., Boyd, P. W., Hunter, K. A., and McTainsh, G. H.: Simulating the cloud processing of iron in Australian dust: pH and dust concentration, Geophys. Res. Lett., 32, L06809, doi:10.1029/2004GL022122, 2005.

Mackie, D. S., Boyd, P. W., McTainsh, G. H., Tindale, N. W., Westberry, T. K., and Hunter, K. A.: Biogeochemistry of iron in Australian dust: From eolian uplift to marine uptake, Geochem. Geophys. Geosyst., 9, Q03Q08, doi:10.1029/2007gc001813, 2008.

Maenhaut, W., Fernández-Jiménez, M.-T., Rajta, I., and Artaxo, P.: Two-year study of atmospheric aerosols in Alta Floresta, Brazil:
Multielemental composition and source apportionment, Nucl. Instrum. Meth. B, 189, 243-248, 2002.

Mahowald, N. M., Baker, A. R., Bergametti, G., Brooks, N., Duce, R. A., Jickells, T. D., Kubilay, N., Prospero, J. M., and Tegen, I.: Atmospheric global dust cycle and iron inputs to the ocean, Global Biogeochem. Cy., 19, GB4025, doi:10.1029/2004GB002402, 2005.

Mahowald, N. M., Engelstaedter, S., Luo, C., Sealy, A., Artaxo, P., Benitez-Nelson, C., Bonnet, S., Chen, Y., Chuang, P. Y., and Cohen, D. D.: Atmospheric iron deposition: Global distribution, variability, and human perturbations*, Mar. Sci., 1, doi:10.1146/annurev.marine.010908.163727, 2009.

Mallet, M., Desservettaz, M., Miljevic, B., Milic, A., Ristovski, Z., Alroe, J., Cravigan, L., Jayaratne, R., Paton-Walsh, C., Griffith, D., Wilson, S., Kettlewell, G., van der Schoot, M., Selleck, P., Reisen, F., Lawson, S., Ward, J., Harnwell, J., Cheng, M., Gillett, R., Molloy, S., Howard, D., Nelson, P., Morrison, A., Edwards, G., Williams, A., Chambers, S., Werczynski, S., Williams, L., Winton, V. H. L., Atkinson, B., Wang, X., and Keywood, M.: Biomass burning emissions in north Australia during the early dry season: an overview of the 2014 SAFIRED campaign, submitted to Atmos. Chem. Phys. Discuss., 2016.

Marx, S. K., Kamber, B. S., and McGowan, H. A.: Estimates of Australian dust flux into New Zealand: Quantifying the eastern Australian dust plume pathway using trace element calibrated $210 \mathrm{~Pb}$ as a monitor, Earth Planet. Sci. Lett., 239, 336-351, 2005.

McTainsh, G., Chan, Y.-C., McGowan, H., Leys, J., and Tews, K.: The 23rd October 2002 dust storm in eastern Australia: characteristics and meteorological conditions, Atmos. Environ., 39, 1227-1236, 2005

Meskhidze, N., Chameides, W., Nenes, A., and Chen, G.: Iron mobilization in mineral dust: Can anthropogenic $\mathrm{SO}_{2}$ emissions affect ocean productivity?, Geophys. Res. Lett., 30, 2085, doi:10.1029/2003GL018035, 2003.

Meskhidze, N., Johnson, M. S., Hurley, D., and Dawson, K.: Influence of measurement uncertainties on fractional solubility of iron in mineral aerosols over the oceans, Aeolian Res., 22, 8592, 2016.

Meyer, C. P., Luhar, A. K., and Mitchell, R. M.: Biomass burning emissions over northern Australia constrained by aerosol measurements: I - Modelling the distribution of hourly emissions, Atmos. Environ., 42, 1629-1646, doi:10.1016/j.atmosenv.2007.10.089, 2008.

Milic, A., Mallet, M. D., Cravigan, L. T., Alroe, J., Ristovski, Z. D., Selleck, P., Lawson, S. J., Ward, J., Desservettaz, M. J., PatonWalsh, C., Williams, L. R., Keywood, M. D., and Miljevic, B.: Aging of aerosols emitted from biomass burning in northern Australia, Atmos. Chem. Phys. Discuss., doi:10.5194/acp-2016-730, in review, 2016.

Mills, M. M., Ridame, C., Davey, M., La Roche, J., and Geider, R. J.: Iron and phosphorus co-limit nitrogen fixation in the eastern tropical North Atlantic, Nature, 429, 292-294, 2004.

Morton, P. L., Landing, W. M., Hsu, S.-C., Milne, A., Aguilar-Islas, A. M., Baker, A. R., Bowie, A. R., Buck, C. S., Gao, Y., and Gichuki, S.: Methods for the sampling and analysis of marine aerosols: results from the 2008 GEOTRACES aerosol intercalibration experiment, Limnol. Oceanogr., 11, 62-78, 2013. 
Pacyna, J. and Nriagu, J.: Atmospheric emissions of chromium from natural and anthropogenic sources, Chrom. Nat. Human Environ., 105-123, 1988.

Paerl, H. W., Crocker, K. M., and Prufert, L. E.: Limitation of $\mathrm{N}_{2}$ fixation in coastal marine waters: Relative importance of molybdenum, iron, phosphorus, and organic matter availability, Limnol. Oceanogr., 32, 525-536, 1987.

Paerl, H. W., Prufert-Bebout, L. E., and Guo, C.: Iron-stimulated $\mathrm{N}_{2}$ fixation and growth in natural and cultured populations of the planktonic marine cyanobacteria Trichodesmium spp, Appl. Environ. Microbiol., 60, 1044-1047, 1994.

Paris, R., Desboeufs, K. V., Formenti, P., Nava, S., and Chou, C.: Chemical characterisation of iron in dust and biomass burning aerosols during AMMA-SOP0/DABEX: implication for iron solubility, Atmos. Chem. Phys., 10, 4273-4282, doi:10.5194/acp10-4273-2010, 2010.

Petzold, A., Ogren, J. A., Fiebig, M., Laj, P., Li, S.-M., Baltensperger, U., Holzer-Popp, T., Kinne, S., Pappalardo, G., Sugimoto, N., Wehrli, C., Wiedensohler, A., and Zhang, X.-Y.: Recommendations for reporting "black carbon" measurements, Atmos. Chem. Phys., 13, 8365-8379, doi:10.5194/acp-13-83652013, 2013.

Raiswell, R., Benning, L. G., Davidson, L., and Tranter, M.: Nanoparticulate bioavailable iron minerals in icebergs and glaciers, Mineral Mag., 72, 345-348, doi:10.1180/minmag.2008.072.1.345, 2008.

Reid, J. S., Koppmann, R., Eck, T. F., and Eleuterio, D. P.: A review of biomass burning emissions part II: intensive physical properties of biomass burning particles, Atmos. Chem. Phys., 5, 799825, doi:10.5194/acp-5-799-2005, 2005.

Reimann, C. and Caritat, P. D .: Intrinsic flaws of element enrichment factors (EFs) in environmental geochemistry, Environ. Sci. Technol., 34, 5084-5091, 2000.

Revel-Rolland, M., De Deckker, P., Delmonte, B., Hesse, P. P., Magee, J. W., Basile-Doelsch, I., Grousset, F., and Bosch, D.: Eastern Australia: A possible source of dust in East Antarctica interglacial ice, Earth Planet. Sci. Lett., 249, 1-13, 2006.

Rubin, M., Berman-Frank, I., and Shaked, Y.: Dust-and mineraliron utilization by the marine dinitrogen-fixer Trichodesmium, Nature Geosci., 4, 529-534, 2011.

Rueter, J. G.: Iron stimulation of photosynthesis and nitrogen fixation in anabaena 7120 and trichodesmium (cyanophyceae), J. Phycol., 24, 249-254, 1988.

Rueter, J. G., Hutchins, D. A., Smith, R. W., and Unsworth, N. L.: Iron nutrition of Trichodesmium, in: Marine pelagic cyanobacteria: Trichodesmium and other Diazotrophs, Springer, Dordrecht, 289-306, 1992.

Schroth, A. W., Crusius, J., Sholkovitz, E. R., and Bostick, B. C.: Iron solubility driven by speciation in dust sources to the ocean, Nature Geosci., 2, 337-340, 2009.

Sedwick, P. N., Sholkovitz, E. R., and Church, T. M.: Impact of anthropogenic combustion emissions on the fractional solubility of aerosol iron: Evidence from the Sargasso Sea, Geochem. Geophys. Geosyst., 8, Q10Q06, doi:10.1029/2007gc001586, 2007.

Shaw, E. C., Gabric, A. J., and McTainsh, G. H.: Impacts of aeolian dust deposition on phytoplankton dynamics in Queensland coastal waters, Mar. Freshw. Res., 59, 951-962, 2008.

Sholkovitz, E. R., Sedwick, P. N., Church, T. M., Baker, A. R., and Powell, C. F.: Fractional solubility of aerosol iron: Synthesis of a global-scale data set, Geochim. Cosmochim. Ac., 89, 173-189, 2012.

Spokes, L. J., Jickells, T. D., and Lim, B.: Solubilisation of aerosol trace metals by cloud processing: A laboratory study, Geochim. Cosmochim. Ac., 58, 3281-3287, 1994.

Sprigg, R.: Some stratigraphic consequences of fluctuating Quaternary sea levels and related wind regimes in southern and central Australia, Quarternary dust mantles, China New Zealand and Australia, Australian National University, Canberra, 211-240, 1982.

Srinivas, B., Sarin, M., and Kumar, A.: Impact of anthropogenic sources on aerosol iron solubility over the Bay of Bengal and the Arabian Sea, Biogeochemistry, 110, 257-268, 2012.

Tagliabue, A., Bopp, L., Dutay, J.-C., Bowie, A. R., Chever, F., Jean-Baptiste, P., Bucciarelli, E., Lannuzel, D., Remenyi, T., Sarthou, G., Aumont, O., Gehlen, M., and Jeandel, C.: Hydrothermal contribution to the oceanic dissolved iron inventory, Nat. Geosci., 3, 252-256, 2010.

Wagener, T., Guieu, C., Losno, R., Bonnet, S., and Mahowald, N.: Revisiting atmospheric dust export to the Southern Hemisphere ocean: Biogeochemical implications, Global Biogeochem. Cy., 22, GB2006, doi:10.1029/2007GB002984, 2008.

Walsh, J. J. and Steidinger, K. A.: Saharan dust and Florida red tides: the cyanophyte connection, J. Geophys. Res.-Ocean., 106, 11597-11612, 2001.

Wedepohl, K. H.: The composition of the continental crust, Geochim. Cosmochim. Ac., 59, 1217-1232, 1995.

Whittlestone, S. and Zahorowski, W.: Baseline radon detectors for shipboard use: Development and deployment in the First Aerosol Characterization Experiment (ACE 1), J. Geophys. Res.-Atmos., 103, 16743-16751, 1998.

Winton, V. H. L., Bowie, A. R., Edwards, R., Keywood, M., Townsend, A. T., van der Merwe, P., and Bollhöfer, A.: Fractional iron solubility of atmospheric iron inputs to the Southern Ocean, Mar. Chem., 177, 20-32, doi:10.1016/j.marchem.2015.06.006, 2015a.

Winton. V. H. L., Edwards, R., and Bowie, A. R.: HR-ICP-MS soluble and total trace element data for Gunn Point, Northern Territory aerosols (June 2014), Curtin University Research Data, doi:10.4225/06/5671012A48C2A, 2015b.

Winton, V. H. L., Bowie, A., Keywood, M., van der Merwe, P., and Edwards, R.: Suitability of high-volume aerosol samplers for ultra-trace aerosol iron measurements in pristine air masses: blanks, recoveries and bugs, Atmos. Meas. Tech. Discuss., doi:10.5194/amt-2016-12, in review, 2016a.

Winton, V. H. L., Edwards, R., Delmonte, B., Ellis, A., Andersson, P. S., Bowie, A., Bertler, N. A. N., Neff, P., and Tuohy, A.: Multiple sources of soluble atmospheric iron to Antarctic waters, Global Biogeochem. Cy., 30, 421-437, doi:10.1002/2015GB005265, 2016b.

Wu, J., Rember, R., and Cahill, C.: Dissolution of aerosol iron in the surface waters of the North Pacific and North Atlantic oceans as determined by a semicontinuous flowthrough reactor method, Global Biogeochem. Cy., 21, GB4010, doi:10.1029/2006GB002851, 2007.

Yamasoe, M. A., Artaxo, P., Miguel, A. H., and Allen, A. G.: Chemical composition of aerosol particles from direct emissions of vegetation fires in the Amazon Basin: water-soluble species and trace elements, Atmos. Environ., 34, 1641-1653, 2000. 